\title{
Voting Rights, Deindustrialization, and Republican Ascendancy in the South
}

\author{
Gavin Wright*
}

\section{Working Paper No. 135}

September 2020

\begin{abstract}
The Voting Rights Act of 1965 revolutionized politics in the American South. These changes also had economic consequences, generating gains for white as well as Black southerners. Contrary to the widespread belief that the region turned Republican in direct response to the Civil Rights Revolution, expanded voting rights led to twenty-five years of competitive two-party politics, featuring strong biracial coalitions in the Democratic Party. These coalitions remained competitive in most states until the Republican Revolution of the 1990s. This abrupt rightward shift had many causes, but critical for southern voters were the trade liberalization measures of 1994, specifically NAFTA and the phase-out of the Multi-Fiber Arrangement which had protected the textiles and apparel industries for decades. The consequences of Republican state regimes have been severe, including intensified racial polarization, loss of support for public schools and higher education, and harsh policies toward low-income populations.
\end{abstract}

https://doi.org/10.36687/inetwp135

JEL Codes: D72, J15, N32, N92

Keywords: African Americans, American South, deindustrialization, voting

* William Robertson Coe Professor of American Economic History, Emeritus 
Voting rights for African Americans are undeniably part of Abraham Lincoln's unfinished legacy. Lincoln himself, in his confidential 1864 letter to Louisiana Governor Michael Hahn, expressed only cautious support for extending the franchise "to some of the colored people....as, for instance, the very intelligent, and especially those who have fought gallantly in our ranks." But when he expressed these sentiments in a public address on April 11, 1865, the prospect of Black voting infuriated audience member John Wilkes Booth and cost Lincoln his life. We will never know with confidence how his views and policies would have evolved had he lived, but Black enfranchisement soon became a priority for Congressional Republicans, embodied in the Military Reconstruction Acts of 1867 and the Fifteenth Amendment to the Constitution, ratified on February 3, 1870. ${ }^{1}$

The keyword here is "unfinished." We now know that Black southerners responded to enfranchisement quickly and in large numbers, electing Black political officials in every state of the former Confederacy. Voting and office holding were purposeful, reflected in efforts to raise taxes, support public schools, and expand access to land ownership. ${ }^{2}$ But we also know that these efforts were crushed by white southern opposition, beginning with violent intimidation in the 1870s and culminating in legal disfranchisement between 1890 and 1910. Although Black registration and voting gradually increased over the next fifty years, the political impact in the South was slight until the landmark Voting Rights Act of 1965.

The VRA revolutionized Black political participation in the South. Black voter registration rates jumped almost overnight in targeted areas and then rose steadily, though voting differences in voting turnout between the North and the South in federal elections only first closed up completely in 2014. ${ }^{3}$ The increase in Black elected officials was longer and slower, requiring extensive litigation to overcome "vote dilution" tactics on the part of white politicians. Subsequently the number of Black elected officials in the South continued to rise throughout the

\footnotetext{
1 "The Late President Lincoln on Negro Suffrage; A Letter from Him to Gov. Hahn of Louisiana," New York Times June 23, 1865; "Last Public Address," Abraham Lincoln Online (accessed 1/9/2020) http://www.abrahamlincolnonline.org/lincoln/speeches/last.htm

${ }^{2}$ Hahn, Nation Under our Feet, pp. 211-12, 244-49; Logan, "Do Black Politicians Matter?"

${ }^{3}$ Turnout differentials vary by elections and times. Federal elections -- Presidential and off year Congressional races - differ systematically from purely state elections often held at different times. See the discussion and statistics in Burnham, Voting in American Elections, which also looks at state races. For the 2014 North/South close up in turnouts see Burnham and Ferguson, "Americans are Sick to Death of Both Parties." Turnouts in most of the rest of the country fell sharply that year.
} 
1980s and 1990s, nearly doubling the non-South by the end of the century. Small wonder that the Act has been hailed as the most successful Civil Rights law in history. ${ }^{4}$

In Sharing the Prize, I showed that enhanced political participation was not just of moral and symbolic value but also contributed positively to the economic wellbeing of Black southerners and the South as a whole. The most immediate gains were in municipalities and counties, where post-VRA surveys found more paved roads and street-lights in Black residential areas, better access to city and county services, and increased Black hires into public-sector jobs, including police and firemen. Advances were also observable at the state level, though Blacks were not close to a voting majority in any southern state. Economists Elizabeth Cascio and Ebonya Washington show that the VRA's elimination of literacy tests was systematically associated with greater increases in state transfers to counties with higher Black population shares. These shifts occurred well before any major Black representation in state government. ${ }^{5}$

The economic gains from broadening the franchise were not limited to African Americans. Contrary to Lyndon Johnson's oft-quoted remark that the Civil Rights Act had "handed the South to the Republicans for a generation," what the VRA actually brought to the South was more than twenty-five years of vigorous two-party competition. Aided by new Black voters, moderate Democrats like John West of South Carolina, Reubin Askew of Florida, and Jimmy Carter of Georgia defeated segregationist opponents in 1970, changing the political landscape for most of the region. Knowing the divisiveness of the race issue, these new-breed governors stressed economic development and education as unifying themes. For a somewhat later period, political scientist Kerry Haynie reports that greater Black representation in state legislatures tended to raise spending on health, education, and social welfare, benefiting southerners of all races. ${ }^{6}$ Energized, or at least not deterred, by these policies, growth in the southern states outpaced the rest of the nation from the 1960s to the 1990s.

\footnotetext{
${ }^{4}$ Edward M. Kennedy, quoted in May, Bending Towards Justice, p. 217. The quotation is from 1981, but Kennedy repeated this assessment throughout his career. He devoted his maiden Senate speech to voting rights and voted for all four renewals of the Act.

5 "Valuing the Vote."

${ }^{6}$ Haynie, African-American Legislators, chapter 4. The states covered were Arkansas, Illinois, Maryland, New Jersey, and North Carolina, for the legislative years 1969, 1979, and 1989. See also Vallely, The Two Reconstructions, p, 199, for evidence of broader effects on southern state budgets, including allocations for hospitals, roads, and libraries.
} 
This essay extends this account to address the question: if the reconfigured political economy of the post-Civil Rights South was so beneficial for almost all concerned, why was it largely abandoned with the consolidation of conservative majorities beginning in the 1990s? One perspective views this outcome as the culmination of a long-term realignment between the ideologies of white southerners and their partisan identities, a process that took time because state party organizations and officeholders were historically Democratic. ${ }^{7}$ Another school of thought stresses the creation of majority-minority districts in response to vote-dilution litigation, reducing incentives toward coalition-building and moderation. ${ }^{8}$ However this may be, state boundaries were not redistricted, yet southern white voting in statewide elections clearly shifted to the right from the 1990s onward. The power of reformulated ideological appeals can hardly be denied, but this essay suggests that another important contributor was the end of rapid regional growth, specifically the massive loss of manufacturing jobs after 1994. This development undermined an important structural basis for biracial political cooperation.

\section{The Historical Path of the Southern Black Vote}

The Fifteenth Amendment to the U.S. Constitution provided that the right to vote could not be denied on the basis of "race, color, or previous condition of servitude," and African Americans participated actively in southern state and local politics for the next two decades, electing more than 600 Black state legislators overall. ${ }^{9}$ With the withdrawal of federal troops in 1876, however, white southerners intensified efforts to repress Black voting. After 1890 disfranchisement became formalized in legislation and in many cases in new state constitutions. By 1910 southern Black disfranchisement was virtually complete. ${ }^{10}$

\footnotetext{
${ }^{7}$ Aistrup, The Southern Strategy Revisited, emphasizes structural constraints and what Larry Sabato calls “30 year's worth of rolling realignment in the South" (p. 60). Hood, Kidd and Morris, The Rational Southerner, describe a dynamic process whereby Black mobilization drove whites into the Republican Party, which then took time to become electorally competitive. Maxwell and Shields, The Long Southern Strategy, attribute realignment to a longterm strategy by Republican leaders to adapt party positions and appeals to deep-seated southern white attitudes and prejudices.

${ }^{8}$ The most prominent critic of these arrangements is Abigail Thernstrom, Whose Votes Count? Thernstrom's views were somewhat modified in her 2008 book Voting Rights -And Wrongs.

${ }^{9}$ Foner, Freedom's Lawmakers. See also Vallely, Two Reconstructions, pp. 23-97.

${ }^{10}$ The landmark quantitative study of disfranchisement is Kousser, The Shaping of Southern Politics. Similar patterns, with great emphasis on informal modes of voter suppression (including lynching) are reported by Jones, Troesken, and Walsh, "A Poll Tax by any Other Name."
} 
It is worth noting that although the racial motivations of southern legislators were blatant and unconcealed, the laws themselves were ostensibly race-neutral in ironic deference to the Fifteenth Amendment, among the most effective instruments being literacy tests and poll taxes (that typically cumulated each year if unpaid). The most direct economic consequences were racial in character, primarily the sharp decline in both absolute and relative spending on Black schools. ${ }^{11}$ But whether by intention or inadvertence, voting by lower-income white southerners was also substantially curtailed by the disfranchisement package, and this group too suffered economic consequences. Statistical studies show a strong three-way association among disfranchisement, plantation tenancy, and educational inequality for both Blacks and whites. ${ }^{12}$ The dual-inequality pattern extended even to North Carolina, exemplifying what Kousser calls "progressivism for middle-class whites only." 13 Such scenarios gave rise to V.O. Key's classic formulation: fixation on race stifled both political competition and progressive economic policies in the South, to the ultimate detriment of low-income members of both races. ${ }^{14}$

Black political leaders never accepted disfranchisement as settled and waged a legal struggle for the vote for more than half a century, with periodic breakthroughs. As early as 1915, the NAACP persuaded the U.S. Supreme Court to invalidate Oklahoma's grandfather clause exempting whites from literacy tests if a linear ancestor had been entitled to vote on January 1, 1866. With the Court's overthrow of the Texas white primary in 1944 (after three decades of litigation), southern Black voter registration began a slow climb, from an estimated 3 percent of the voting-age population in 1940 to 12 percent in 1947 and 20 percent in $1952 .{ }^{15}$ Black voters in this era were mainly in cities and could sometimes exercise political influence in competitive elections. But progress during the 1950s was painfully slow, and this stasis was hardly changed by the Civil Rights Acts of 1957 and 1960. Between 1960 and 1962 the estimated southern Black registration rate barely budged, from 29.1 to 29.4 percent. $^{16}$

\footnotetext{
${ }^{11}$ Margo, Disfranchisement, School Finance, and the Economics of Segregated Schools, Table I-1. ${ }^{12}$ Gerber, "Public School Expenditures in the Plantation States;" Halicoussis, Ng and Virts, "Property Ownership and Educational Discrimination in the South;" Walters, James and McCammon, "Citizenship and Public Schools."

${ }^{13}$ Kousser, "Progressivism for Middle-Class Whites Only," p. 191.

${ }^{14} \mathrm{Key}$, Southern Politics in State and Nation.

${ }_{15}$ Price, The Negro Voter in the South and The Negro and the Ballot in the South.

${ }^{16}$ Watters and Cleghorn, Climbing Jacob's Ladder, p. 376; Garrow, Protest at Selma, pp. 11, 19. This paragraph also draws upon Lawson, Black Ballots, pp. 23-85.
} 
The historic break came in 1962, with the launching of the Voter Education Project, a mass registration project sponsored by five Civil Rights organizations and encouraged by the Kennedy administration. The campaign registered approximately 700,000 voters in two and a half years. But it also provoked considerable resistance and retaliation, and some states (notably Alabama, Louisiana, and Mississippi) saw minimal gains at best. Thus the Johnson administration was preparing more aggressive federal legislation even before the dramatic showdown at Selma on March 7, 1965. ${ }^{17}$

The Voting Rights Act of 1965 rewrote the rules of southern politics almost overnight. Sections 2 and 3 restated the principles of the Fifteenth Amendment nationally. Section 4 defined a "coverage formula" for federal action: jurisdictions that imposed a literacy test or similar device and where voter turnout was less than 50 percent in the 1964 Presidential election. These criteria covered six southern states fully (Alabama, Georgia, Louisiana, Mississippi, South Carolina and Virginia) plus about forty counties in North Carolina. Literacy tests were banned entirely in covered areas, and the Attorney General was authorized to assign federal examiners to enroll qualified voters in these areas. Within the first three months of enactment, Attorney General Katzenbach sent examiners to thirty-two counties in four states. By the end of 1967, examiners had registered more than 150,000 Black southerners in fifty-eight counties. More than twice this number were registered by local voting registrars elsewhere, under the threat of federal intervention if prior practices did not change. ${ }^{18}$

\footnotetext{
${ }^{17}$ Lawson, Black Ballots, pp. 261-287. On the 1962 turning point, see Timpone, "Mass Mobilization or Government Intervention?"

18 This paragraph draws on Lawson, Black Ballots, pp. 307-330; U.S. Commission on Civil Rights, Political Participation, pp.11-13.
} 


\section{Figure 1 Southern Black Voter Registration 1940-2018}

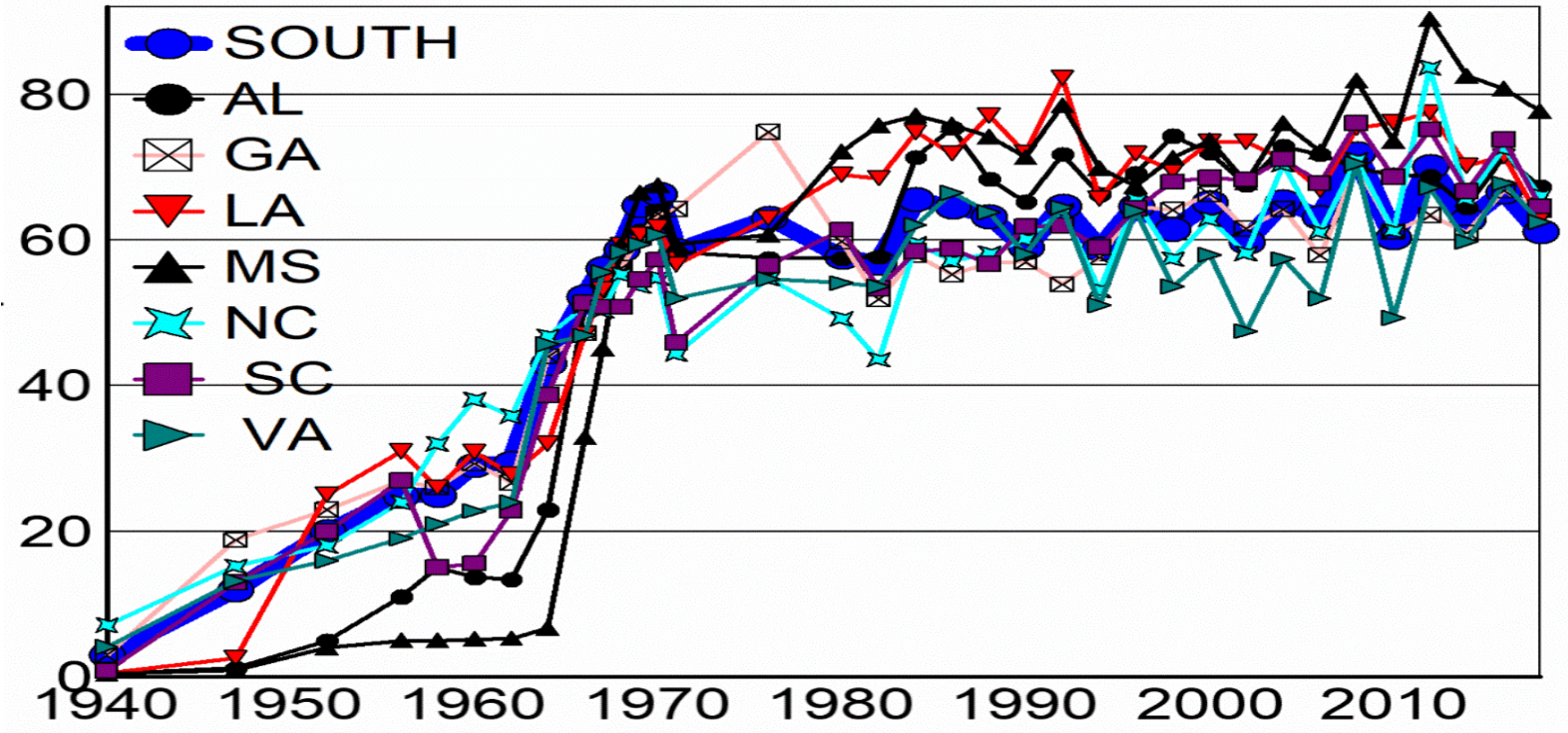

SOURCES: Voter Education Project, as compiled by Garrow, Protest at Selma, pp. 7, 11, 19, 189, 200 (1940-1971); and as compiled by Stanley, Voter Mobilization, p. 97 (1976-1980). U.S. Census Bureau, Current Population Survey, Reported Voting and Registration by Sex, Race and Hispanic Origin, for States (1980-2014).

Figure 1 shows the sharp jump in Black voter registration between 1965 and 1970 in the seven original VRA states and the South as a whole. The increase was substantial even in states where growth was fairly steady from 1940 onward, but the discontinuity was particularly marked in Alabama, Mississippi, and South Carolina. The figure also shows that these higher registration levels were largely maintained in subsequent decades, albeit with fluctuations. By the 1980s, southern Black registration rates were typically higher than those of Blacks in other regions, at times exceeding white registration rates in the same state and year.

The 1965 Act was an emergency measure set to expire in five years. President Richard Nixon came into office intending to get the voting rights "monkey ... off the backs of the South" by extending coverage nationwide and eliminating Section 5, which required "preclearance" of 
any change in election procedures in covered areas. In the end, however, the Act was renewed in 1970 for another five years little changed, though the ban on literacy tests did indeed become national at that time. The 1975 renewal was for seven years and extended coverage to language minorities, a provision championed by Barbara Jordan of Texas, the first Black woman ever elected to Congress from the South. By that time, the VRA had acquired significant support from within the South: 52 of 78 southern Democrats voted in favor, and 10 of 27 southern Republicans; in the Senate, a regional majority of eleven Democrats and two Republicans from the South voted for renewal. Some of the change may have been merely a matter of acquiescence to what had become a national consensus. But it also reflected the observation that experience under the VRA had by no means been as calamitous as white southerners anticipated. As Louisiana Democratic Senator Bennett Johnston put it: "We found that the sky did not fall under the 1965 Voting Rights Act, that things worked pretty well in the South, the deep South of the old Confederacy, which readjusted their patterns of voting, readjusted their attitudes towards all people. It worked." As if in confirmation of the emerging consensus within the region, every southern governor joined in designating July 1976 "Voter Registration Month,” urging all unregistered persons to register and vote in the bicentennial year. ${ }^{19}$

The VRA survived even the Reagan revolution of the 1980s, which curtailed or reversed many other aspects of Civil Rights policy. Encouraged by Strom Thurmond of South Carolina, Reagan initially favored extending Section 5 to all of the states, a transparent means of diluting enforcement in the South. Despite vigorous efforts by Reagan's team, strong Congressional majorities voted not only for a 25-year renewal in 1982, but also to reverse the Supreme Court's 1980 ruling that vote dilution was actionable only if discriminatory intent could be established. This time the final votes in both houses were nearly unanimous, only four of twenty-two southern Senators in opposition. Thurmond himself, not wanting to antagonize South Carolina's Black voters, supported renewal for the first time. It would hardly seem possible that the VRA consensus could grow any stronger, but in fact the 2006 renewal vote continued the trend.

\footnotetext{
${ }^{19}$ Berman, Give Us the Ballot, p. 118. The Bennett quotation is from Lawson, In Pursuit of Power, p. 252. This paragraph draws on Lawson, Pursuit of Power, pp. 130-157, 226-253; and Berman, Give Us the Ballot, pp. 76-78, 82-86, 95-99, 105-113.
} 
Majorities for another 25-year renewal in that year were even more overwhelming in both the Senate (98-0) and the House (390-33). ${ }^{20}$

\section{Black Elected Officials}

The surge in Black voters was accompanied by an upward jump in Black candidates for office. There were several striking early successes in Black-majority areas. Newly enfranchised voters in Macon County, Alabama, elected a Black sheriff for the first time in 1966. The Freedom Democratic Party of Mississippi successfully backed Robert Clark of Holmes County in his election to the state house of representatives in 1967. By 1974, in the states covered by the VRA, nearly a thousand Black officials were serving, compared to just seventy-two in 1965. Nonetheless a report by the U.S. Commission on Civil Rights on the tenth anniversary of the VRA found that Black representation was still far below its demographic potential, so that “minorities have not yet gained a foothold on positions of real influence."21

A central reason for the lag in Black representation was the adoption of an array of measures by southern jurisdictions to weaken the effectiveness of Black voting, a practice known as "vote dilution." The Civil Rights Commission devoted more than half of its 1968 report to documenting these practices, which included changing from district to county-wide elections; consolidating adjoining counties to increase the share of white voters; abolishing elective offices contested by Black candidates; imposing additional filing fees and requirements for elective office; withholding essential information for contesting a public office; and many others. ${ }^{22}$

The particularly egregious actions by the state of Mississippi led to the decision in Allen v. State Board of Education (1969), in which the Supreme Court declared that all changes in electoral procedures in covered areas must be submitted to the Attorney General for preclearance, giving an expansive reading to the Act's language authorizing "all actions

\footnotetext{
${ }^{20}$ This paragraph draws on Berman, Give Us the Ballot, pp. 136-158, 233-244. The unanimity of the 2006 renewal should not be taken to mean that there were no signs of impending change in Republican political strategy. D. KingMeadows argues that members of Congress, even while supporting renewal, "sowed and watered the seeds of judicial skepticism," laying the groundwork for the coming effort to weaken the VRA through the courts (When the Letter Betrays the Spirit, pp.93-112.) A comprehensive account of the campaign to dismantle the protections of the Act appears in Rutenberg, "Overcome," New York Times Magazine August 2, 2015.

${ }^{21}$ U.S. Commission on Civil Rights, The Voting Rights Act: Ten Years After, p. 336. The figures on Black elected officials in covered states are from the same report, p. 328. The early electoral successes are described in Lawson, In Pursuit of Power, pp. 99, 107.

${ }^{22}$ U.S. Commission on Civil Rights, Political Participation, pp. 19-31. An update, reporting some progress but much persistence, appeared in the 1975 report (Ten Years After), pp. 131-172.
} 
necessary to make voting effective." The court's pendulum swung the other way in Mobile v. Bolden (1980), which held that vote dilution was only actionable if discriminatory intent could be established. This restriction was promptly reversed by Congress in the 1982 renewal of the VRA, illustrating the strength of the national consensus in support of meaningful Black political participation. The new language provided that voting violations need only have a "discriminatory effect," not necessarily a "discriminatory purpose," to be proscribed. The Supreme Court revisited the issue in Thornburg v. Gingles (1986), a case emerging from a North Carolina redistricting plan that spread Black voters across seven new Congressional districts in such a way that no Black candidate was likely to be elected. This time the court ruled that six of the new districts violated the Act, endorsing criteria based on the "totality of circumstances" in the area, including the size and cohesiveness of racial voting blocs and the history of racially polarized voting. The outcome of this historical process was in essence a conclusion that the Voting Rights Act required the creation of Black-majority legislative districts in the South. ${ }^{23}$

Figure 2 illustrates the results for Black elected officials, comparing the eleven-state South to the rest of the nation. The litigation-driven accelerations of the 1980s and 1990s are evident. It is notable that by the 1984, the number of Black elected officials in the South surpassed that of the non-South, where progress on this front stagnated. A statistical analysis published in 1994 concluded that the transition was largely driven by Black-majority districts compelled by enforcement of the Voting Rights Act. ${ }^{24}$

\footnotetext{
${ }^{23}$ This summary draws upon Lawson, In Pursuit of Power, pp. 168-188; Davidson and Grofman, Quiet Revolution in the South, pp. 21-37.

${ }^{24}$ Davidson and Grofman, Quiet Revolution, pp. 335-350. An account of the politics behind the reapportionments of 1992 appears in Berman, Give Us the Ballot, 186-192.
} 


\section{Figure 2 Black Elected Officials South and Non-South, 1969-2002}

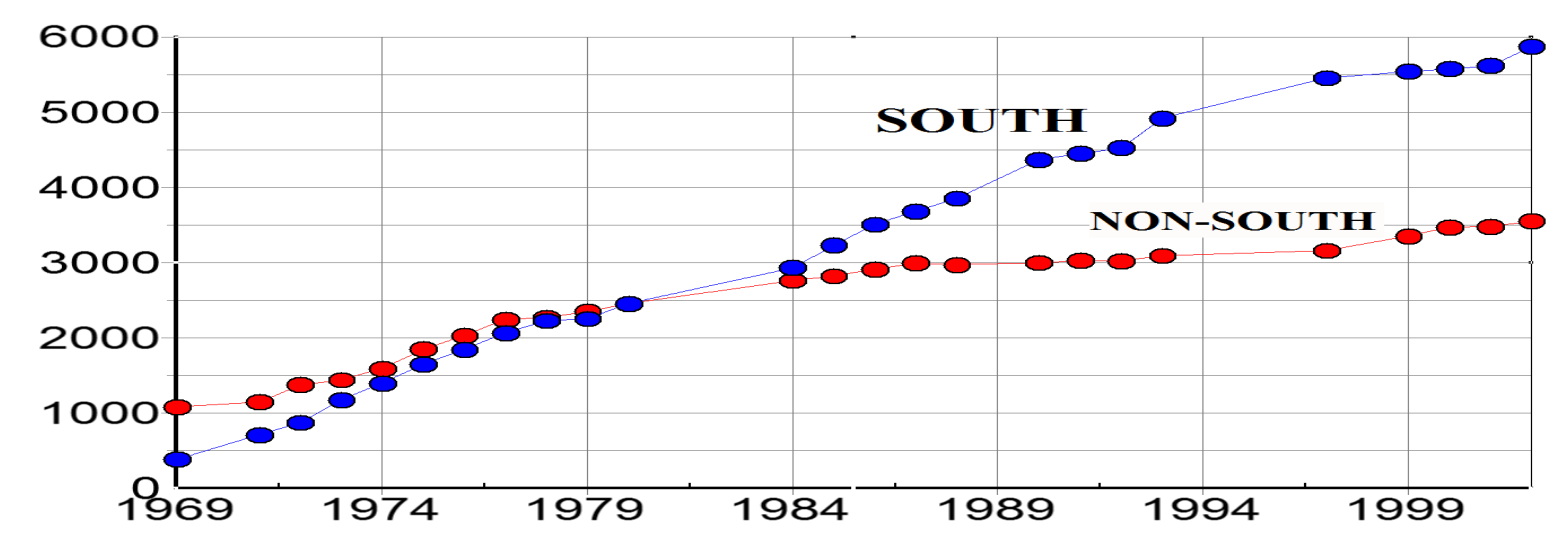

Source: Joint Center for Political and Economic Studies, Black Elected Officials, various issues.

Another regional aspect of the "quiet revolution" is illustrated in Table 1, which considers the share of Black elected officials relative to the Black share of the voting-age population, for the South and the Non-South, in 2001. Although southern Black citizens were still underrepresented by this measure in most offices, the degree of representation was much higher than elsewhere in the country, relative to the size of the Black population. True enough, most BEOs in the South were in local government positions, such as county commissioners, city councilors, and school board members. But Black candidates also gained seats in southern state legislatures, and these too had their greatest growth spurts in the 1980s and 1990s..$^{25}$

Intentional creation of majority-minority districts was controversial at the time and continues to be so. On the one hand, grouping voters by race may reduce incentives for interracial cooperation and coalition-building. Against this, there is much evidence that a visible Black presence in elected leadership positions makes a difference, both subjectively and objectively. A Black political organizer in Mississippi remarked: “The number of victories isn't as important as the fact that they symbolize a bit of Black authority, a gradual return to respect for those accustomed to having their lives manipulated by white hands." ${ }^{26}$ Tom McCain, the first

\footnotetext{
${ }^{25}$ See the state tables in Bullock and Gaddie, Triumph of Voting Rights, pp. 42, 68, 92, 124, 148, 176, 204. The Joint Center for Political and Economic Studies ended its annual review of Black elected officials in 2002. Later surveys are not directly comparable, but they suggest that the basic regional patterns have persisted. For 2006 figures, see The Gender and Multi-Cultural Leadership Project (GMCL.org).

${ }^{26}$ Quoted by Lawson, In Pursuit of Power, p. 301.
} 
Black candidate for office in Edgefield County, South Carolina, since Reconstruction, argued: "There's an inherent value in office-holding that goes far beyond picking up the garbage. A race of people who are excluded from office will always be second class. ${ }^{27}$ Beyond mere perceptions are the many services that Black representatives provide for their constituents. Studies of Congress show that although the racial composition of delegations has little effect on roll-call votes, Black representatives make a decisive difference for constituency services, hiring Black staff members, locating district offices, and establishing a sense of trust with Black voters. ${ }^{28} \mathrm{~A}$ Black official in Panola County, Mississippi, noted: "Blacks feel they can come to me and get answers to problems; they have a connection with the system."29

Because federal and state legislative districts have been subject to change through judicial and political processes, this essay concentrates on statewide elections, where no redistricting has occurred. Indeed, one of the clearest indications that race remains politically salient in the South is that elections of Black candidates to statewide office in the South has been and continues to be extremely rare. In modern times, no Black candidate has been elected to a state constitutional office in Alabama, Arkansas, Louisiana, Mississippi, Tennessee, or Texas. The two most conspicuous counter-examples - Douglas Wilder of Virginia and Tim Scott of South Carolina are both exceptions that tend to prove the general rule. Wilder was first elected as lieutenant governor in 1985, and then governor in 1989; both elections were extremely close, and the bulk of Wilder's white votes came from northern counties and Hampton Roads, fast-growing areas with large nonnative populations..$^{30}$ Tim Scott is a conservative Republican who was appointed to a vacant U.S. Senate seat by Governor Nikki Haley in 2013 and then elected for the remainder of the term in 2014. Although Scott's election confirms that southern white attitudes toward race have changed since Civil Rights days, his political isolation also underscores the extent to which race and partisan polarization have become closely intertwined in the contemporary South.

\footnotetext{
${ }^{27}$ Quoted in Thernstrom, Voting Rights - and Wrongs, p. 14.

${ }^{28}$ Grose, Congress in Black and White, pp. 7-9, 87-109, 110-133.

${ }^{29}$ Wirt, “We Ain't What We Was,”,p. 69.

${ }^{30}$ Davidson and Grofman, Quiet Revolution, p. 278. North Carolina elected a black attorney general in 1992. Georgia elected African Americans to various state offices in 1998, 2002, and 2006.
} 


\section{Economic Gains from Voting Rights}

A large question looming over this discussion is whether the advent of voting rights actually enhanced the wellbeing of African Americans in the South. One direct effect was to reduce and then virtually eliminate the extreme racial rhetoric that had long characterized southern campaigns. Knowledgeable observers of South Carolina politics reported: “The increase in African American voter registration and turnout almost immediately ended the white supremacist rhetoric that had been a hallmark of the state's political leaders." ${ }^{31}$ In the 1967 Mississippi gubernatorial election, "neither of the two major candidates dared praise segregation as overtly as had the candidates four and eight years earlier." ${ }^{2}$ True, a die-hard segregationist candidate like Lester Maddox could make a political splash, becoming governor of Georgia in 1967. But even Maddox in office moderated his racial rhetoric, and he was succeeded in 1971 by Jimmy Carter, an outspoken racial progressive. The year 1970 marked something of a turning point, in which traditional racial rhetoric proved politically unsuccessful throughout the South. In that year, former Dixiecrat Strom Thurmond of South Carolina backed a segregationist gubernatorial candidate, who lost to moderate Democrat John West. Having gotten the message, Thurmond became the first southern senator to appoint a Black staff aide and the first to sponsor an African American for a federal judgeship. For the rest of his career, Thurmond actively sought Black votes, with moderate success. ${ }^{33}$ Five years after passage of the Voting Rights Act, Black voting seemed clearly to be a force for political moderation. ${ }^{34}$

Moderation in local politics also generated improved access to city and county services, such as police and fire protection, paved roads and street lights, recreational facilities, and appointments to boards, commissions and civil service jobs. ${ }^{35}$ Systematic evidence compiled by political scientist James Button for six Florida counties shows that the percentage of streets

\footnotetext{
${ }^{31}$ Davidson and Grofman, Quiet Revolution, p. 215. The South Carolina chapter was written by Orville Vernon Burton, Terence R. Finnegan, Peyton McCrary, and James W. Loewen.

${ }^{32}$ Havard, The Changing Politics of the South, p. 509. The Mississippi chapter was written by Charles N. Fortenberry and F. Glenn Abney.

${ }^{33}$ Cohodas, Strom Thurmond, pp. 412-413, 451; Stanley, Voter Mobilization, pp. 142-143. George Wallace himself dropped racial rhetoric from his third inaugural address in 1975, and in 1979 told the New York Times: "It's good that it's a racial situation being changed. It's good that the civil rights bill has passed. It hasn't been the evil that we thought" (quoted in Braden, "The Speaking of the Governors of the Deep South," p. 199).

${ }^{34}$ May, Bending Toward Justice, pp. 181-191.

35 Wirt, Politics of Southern Inequality, pp. 166-175; Lawson, Black Ballots, p. 339; Hanks, The Struggle for Black Political Empowerment, pp. 65-66.
} 
paved in Black subcommunities was far below the white norm in 1960, but rose rapidly in the 1960s and was at or near parity with white areas by the 1980s. As the white mayor of Titusville explained: "Through the early 1960s the city council was composed of an old-line group of people - rural, southern, been here all their lives, and some of whom still carried Civil War memories. Blacks did not receive their fair share of services because they were considered second-, or even third-class citizens." 36

Black voting and representation produced tangible economic benefits by changing the racial composition of public-sector employment. ${ }^{37}$ The biggest increases in Black public-sector employment were in large cities with Black city councils and mayors. When Atlanta first elected a Black mayor in 1973, Black employment rose from 38.1 to 55.6 percent of the total; Black administrators jumped from 7.1 to 32.6 percent, and professionals from 15.2 to 42.2 percent. ${ }^{38}$ In Richmond, Virginia, Black city employment was restricted to service and maintenance jobs until 1963. Blacks attained a majority in the city council in 1977 , after redistricting in response to a Supreme Court ruling rejecting a proposed annexation. As a direct result, the parity score for minority employment increased from 0.756 to 1.10 . As in Atlanta, employment shares rose most rapidly in administrative and professional categories. ${ }^{39}$ Some of these gains may have happened even without local political voice, because the 1972 amendments to the Civil Rights Act extended Title VII coverage to the public sector. But Black political representation also clearly made a difference. Using a national panel of cities and metropolitan areas for 1971-2004, economists John V.C. Nye, Ilia Ranier, and Thomas Stratmann find that election of a Black mayor in a city with a large Black population had a large positive impact on Black employment in both public and private sectors, labor force participation, and income. ${ }^{40}$

Similar effects are also found in studies of VRA impacts at the county level. Comparing covered and non-covered North Carolina counties in the mid-1980s, political scientist Joel Thompson reported that the VRA counties had greater increases in Black voter registration and elected officials, but also more rapid growth in Black incomes and occupational status, and

\footnotetext{
${ }^{36}$ Button, Blacks and Social Change, p. 71. The data on paved streets is presented in Table 5.1.

${ }^{37}$ Gainous, Button, and Rienzo, “African Americans and Municipal Employment;” Button, Rienzo and Croucher, The Political Economy of Employment, pp. 75-102; Wirt, “We Ain't What We Was,” pp. 72-74.

${ }^{38}$ Eisinger, "Black Employment in Municipal Jobs," p. 385.

${ }^{39}$ Byng, "Responding to Black municipal Interests," pp. 209-233.

${ }^{40}$ Nye, Ranier, and Stratmann, "Do Black Mayors Improve Black Employment Outcomes?"
} 
attracted more revenue from both county and outside governmental sources. A later study by Abhay P. Aneja and Carlos F. Avenancio-Leon compares covered and non-covered counties throughout the South between 1950 and 1980, showing that coverage reduced Black-white wage gaps, by expanding public sector employment opportunities for Black workers and by support for anti-discrimination policies. Economists Andrea Bernini, Giovanni Facchini, and Cecelia Testa find that southern counties more strongly affected by the VRA - in that they were compelled by litigation to switch to single-member districts - elected more Black officials, gained more revenue from state and federal transfers, and provided more public goods, primarily education. ${ }^{41}$

Most of the foregoing examples are from jurisdictions in which Black voters constituted a majority or near majority of the electorate. There is evidence, however, that economic gains were also realized through the policies of states, none of which had Black majorities even after the registration surge impelled by the VRA. The most thoroughly documented study is by Elizabeth Cascio and Ebonya Washington, who track the share of state transfers (chiefly for education) to counties with higher Black population shares, comparing states with literacy tests (and therefore covered by the VRA) and those without. The authors estimate that the mean county in a literacy-test state saw an increase of 16.4 percent in per-capita transfers over the period. Citing contemporary testimony, Cascio and Washington interpret the result as an indication that Blacks were part of new statewide coalitions. The shift in state resource allocation was strongly associated with increased turnout in presidential elections but occurred well before any major Black representation in state government. ${ }^{42}$

The case for positive economic benefits for African Americans from voting seems strong. A further question raised in Sharing the Prize is whether these advances came at the expense of white southerners, or whether instead they were part of a broader restructuring by which most white southerners also gained. If we define progress in terms of shares - of fund transfers, public services, or employment - then the game is zero-sum by definition. But if Black political participation facilitated biracial cooperation towards mutually beneficial goals, then both races may have been net winners. Many local studies describe precisely this outcome. Returning to

\footnotetext{
${ }^{41}$ Thompson, "The Voting Rights Act in North Carolina," pp. 144, 149, 151; Aneja and Avenancio-Leon, "The Effect of Political Power on Labor Market Inequality;" Bernini, Facchini, and Testa, "Race, Representation and Policy."

${ }^{42}$ Cascio and Washington, "Valuing the Vote."
} 
Panola County, Mississippi, after a twenty-year absence, Frederick Wirt found: "Among white leaders of Panola County there was a general sense that voting changes had benefited not merely Blacks but whites as well... Whites reported that Black empowerment had helped them overturn the old power holders and the planters who had blocked racial and economic change." 43 Cooperation to attract community health centers into underserved areas is a good illustration of the potential return to inter-racial coalitions. Health care historian Bonnie Lefkowitz writes: "In South Carolina, Mississippi, and Texas, the centers not only drew strength from the civil rights movement, they irrevocably altered the white power structure that controlled the economic and environmental determinants of disease." ${ }^{44}$

Major southern cities also developed biracial coalitions in the wake of Black political empowerment. In Birmingham, Alabama, a city beleaguered by racial conflict and industrial decline, new Black voters supported long-stymied city government reform and bond issues to improve municipal services. The twenty-year administration of the first Black mayor, Richard Arrington, was marked by collaboration with the largely white business community and a development program centered on the University of Alabama, Birmingham and its medical complex. ${ }^{45}$ Another successful biracial coalition was in Charlotte, North Carolina, which struggled to an uneasy compromise on school integration and busing in the 1970s. A move to district representatives in 1977 increased Black participation and contributed to passage of an airport bond issue in 1978, reversing an earlier defeat. The election of Civil Rights hero Harvey Gantt as mayor in 1981 seemed to symbolize the post-Civil Rights consensus around economic growth, helping Charlotte to become the third-largest banking center in the nation. ${ }^{46}$ Perhaps the most famous example of biracial growth is Atlanta, which emerged from 1960s turmoil to the status of world-class city: fourth-largest concentration of Fortune 500 companies, world's busiest airport, home of prominent universities and high-tech industries - with Black political leadership

\footnotetext{
${ }^{43}$ Wirt, “We Ain't What We Was,” p. 67. Similar accounts appear in Perry, "The Socioeconomic Impact of Black Political Empowerment;” McDonald, Voting Rights Odyssey, pp. 238-245.

${ }^{44}$ Lefkowitz, Community Health Centers, p. 137. See also Greene, Praying for Sheetrock, p. 250, an account of McIntosh County, Georgia, where Black political representation was delayed until 1978, but was then followed by an extensive influx of federal funding for health and sanitation facilities.

45 Thornton, Dividing Lines, pp. 370-379; Perry, "The Evolution and Impact of Biracial Coalitions;” Connerly, "The Most Segregated City in America,” pp. 102-128.

${ }^{46}$ Smith, Boom for Whom, pp. 217-220.
} 
since 1974. Atlanta's progress has been sufficient to attract an influx of young, educated predominantly white people into the city since $1990 .{ }^{47}$

\section{The Voting Rights Act and the Two-Party South}

The most stringent test for the proposition that Black voting rights were broadly beneficial is the effect on the political climate in statewide elections. Among the best-known quotations from the Civil Rights era is Lyndon Johnson's reported remark to Bill Moyers after signing the historic 1964 bill: "I think we just handed the South to the Republicans for a long time to come." The statement is repeated because it seems prophetic: the twenty-first century South is solidly Republican, and the region has been voting that way in Presidential elections since the 1970s. But as commonly used, the quote is deeply misleading. Johnson knew that the Civil Rights Act had damaged him with the white South, but he also believed that the Voting Rights Act of 1965 would repair much of this loss, by making moderate southern Democrats competitive. In a memo entitled "Negro Vote in the South," Presidential aide Lawrence O'Brien pointed out that Black voters had provided LBJ's margin of victory in four southern states. ${ }^{48}$ Martin Luther King, Jr., expanded on this argument in a January 1965 phone conversation with Johnson: "It's very interesting, Mr. President, to note that the only states you didn't carry in the South...have less than forty percent of the Negroes registered to vote...It's so important to get Negroes registered in large numbers in the South. It would be this coalition of the Negro vote and the moderate white vote that will really make the new South." 49

King's vision of a successful biracial coalition was largely borne out in statewide elections over the next 25-30 years. Figures $3 \mathrm{a}$ and $3 \mathrm{~b}$ show the distribution of U.S. Senators and governors by party from 1960 to 2019. Republican strength rose from near-zero between 1965 and 1970, but Democrats continued to be competitive through the 1990s. Southern Democratic governors outnumbered Republicans as late as 2002.

\footnotetext{
${ }^{47}$ Jarrod Apperson, “An Afterward to White Flight: Atlanta's Return to Community \& Long Road Toward Integration," East Atlanta Patch (February 10, 2013).

${ }^{48}$ Stern, Calculating Visions, p. 211.

${ }^{49}$ Quoted in Vallely, Two Reconstructions, p. 198.
} 
Figure 3a. Southern Senators by Party, 1960-2019

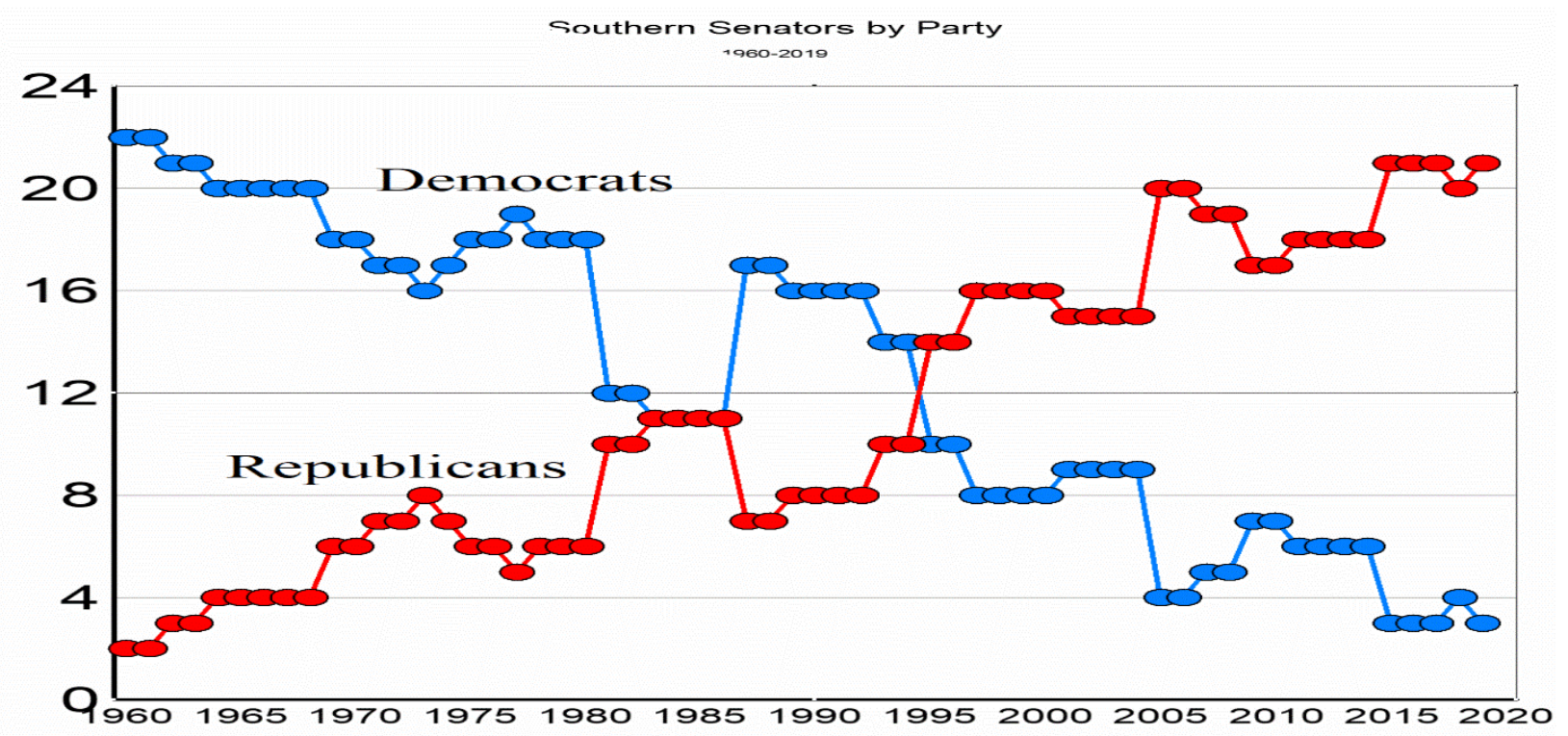

Figure 3b. Southern Governors by Party, 1960-2019

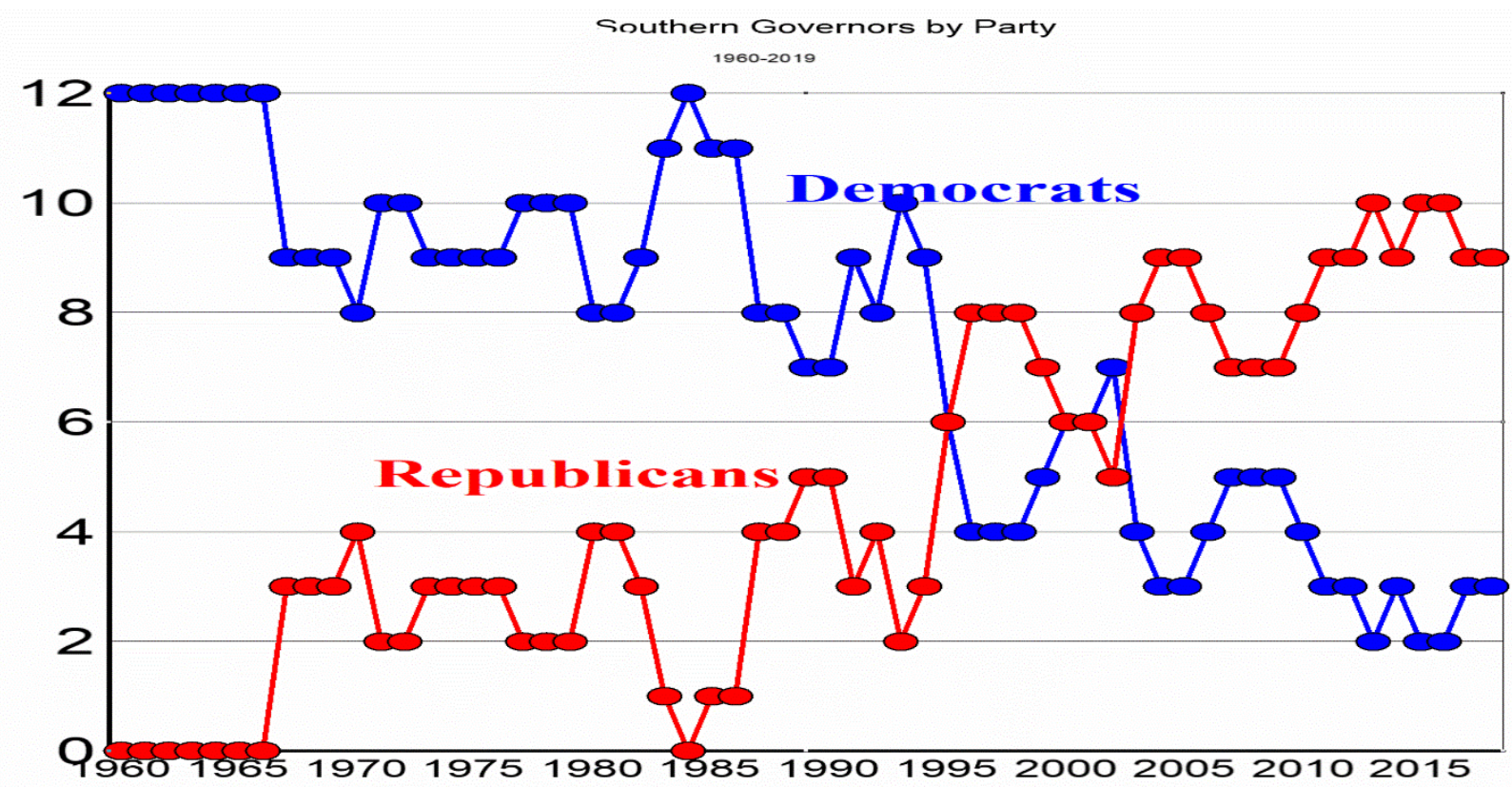

A count of office-holders is not necessarily a good measure of inter-party competition, because it does not tell us what was happening within the states. A tool commonly used by political scientists is the Ranney Index, which aggregates each party's proportion of success (percentage of votes for governor, percentage of legislative seats), duration of success (length of time under party control), and frequency of divided government. A summary of state indices by 
time period appears in Table 2, adapted to federal elections by J. David Woodard. The picture is much the same as in Figures 3a and 3b. For 1956-1962, all the southern states were classified as One-Party Democrat. Between 1964 and 1978, five states became Two-Party Competitive (Florida, South Carolina, Tennessee, Texas, and Virginia). Between 1980 and 1994, nine of the eleven states were Two-Party Competitive. Illustrating that these categorizations are far from permanent, two states (North Carolina and Virginia) actually reverted from One-Party Republican to Two-Party Competitive between periods. True, the table shows a strong rightward shift after 1994. The point is that the move into One-Party Republican rule is historically very recent in most southern states.

Such indices do not necessarily capture the changes in voting behavior we are after, because differences between Presidential and state voting can persist for long periods, and because congressional elections (both state and federal) are subject to influence by redistricting. Figure 4a displays the Democratic share of the vote in all southern statewide elections from 1960 to 2016 . The trend from 1970 to 1992 is barely perceptible, the average falling by less than two percentage points. The trend is slightly faster when only Senate votes are included (Figure 4b), but here too, the decisive shift came in 1994. ${ }^{50}$

Figure 4a. Democratic Share of State Votes, 1960-2016

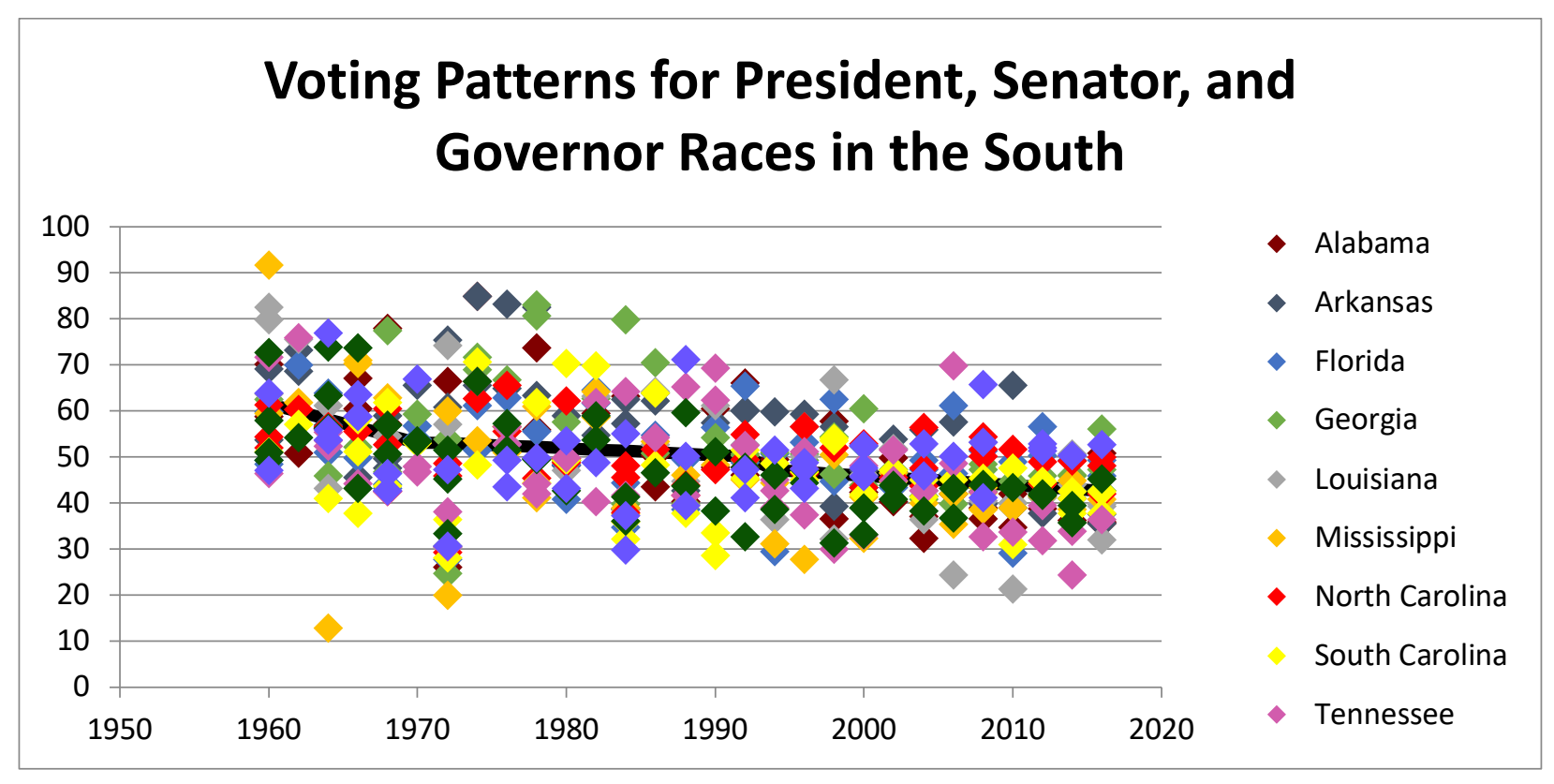

${ }^{50}$ Gaddie and Hoffman, "Critical Events in Southern Politics,” p. 31. 


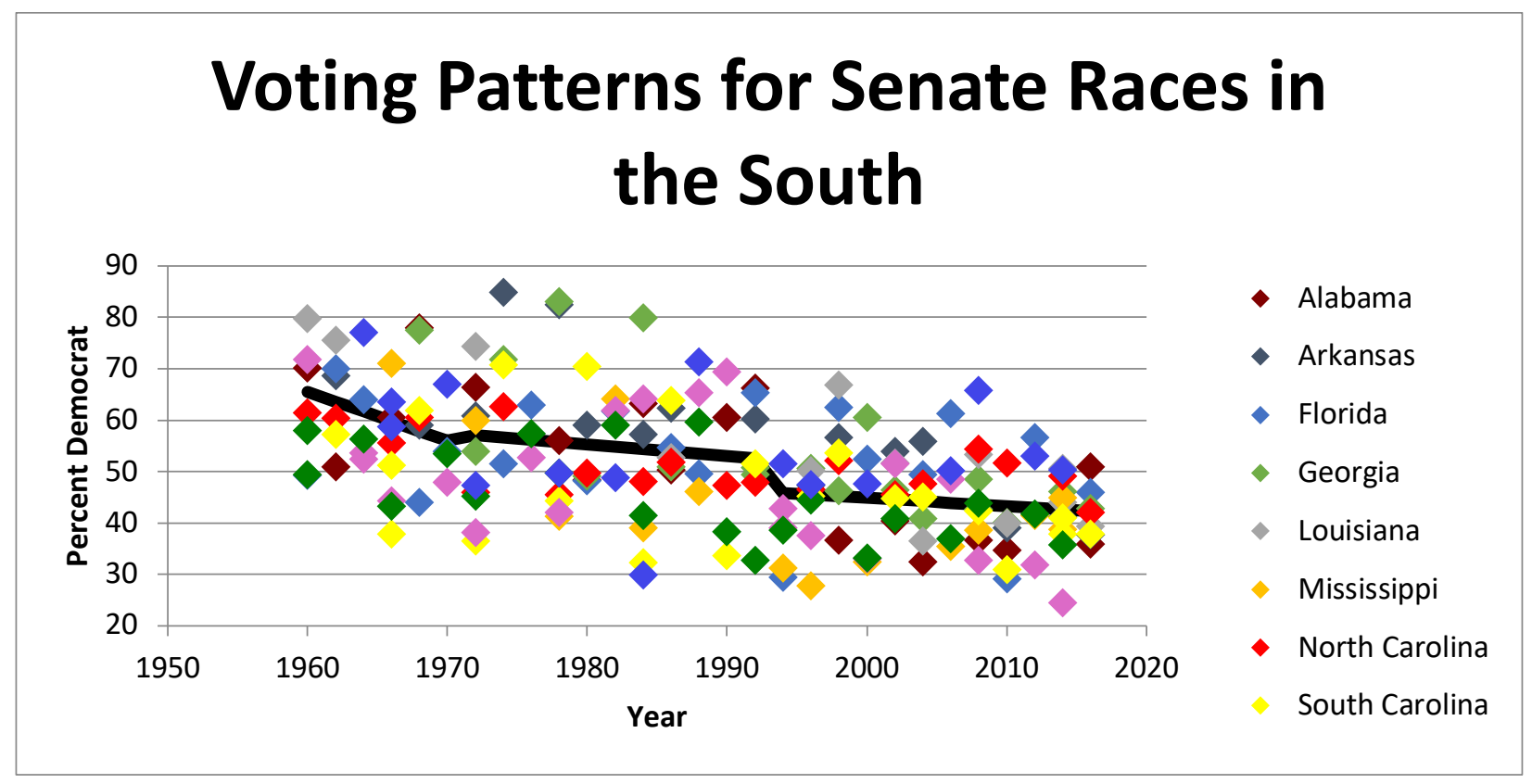

Because 1994 was the year in which the Republicans gained control of the House of Representatives (for the first time since the 1950s), the relatively sudden shift in partisan balance is often attributed to the redistricting decisions of the early 1990s. But Ebonya Washington compares Congressional political outcomes (party and ideology) in redistricted states litigation with those in southern states not covered by the VRA, finding no significant difference between the two. Political scientists John R. Petrocik and Scott W. Desposato show that the direct effect of reshuffling Black and white voters had no more than a minor impact on short-term partisan results. The critical factor, in their view, was a "pro-GOP surge, independent of redistricting... an impossible-to-anticipate, large, anti-Democratic tide." ${ }^{51}$ In any case the shares in Figures 4a and 4b are for states, whose boundaries did not change. In 1994, Republicans won five of six southern Senate races, and four of seven governorships. It appears that the trend as well as the level shifted, a genuine regime change in regional politics.

Looking back from the twenty-first century, many writers are inclined to see the transition to a Republican South as inevitable, a "process [that] took decades to completely sort itself out" but was nonetheless bound to happen. On this view, realignment was constrained only

\footnotetext{
${ }^{51}$ Washington, “Do Majority-Black Districts Limit Blacks' Representation?" esp. p. 266; Petrocik and Desposato, "Partisan Consequences of Majority-Minority Redistricting," pp. 613, 630.
} 
by the need to build an infrastructure of Republican support networks and "viable Republican candidates who campaigned on a message that was in step with the views of white southerners." The premise of this interpretation is that the white South "has never changed fundamentally, in a political sense or even a cultural one." As one recent observer puts it: "Why did Democrats lose the white South? ...Because the party became too liberal on civil rights and racist white Southerners didn’t like it." 52

Such interpretations are unhistorical. Knowledgeable observers of southern politics during the 1970 s and 1980 s did not portray a shaky temporary waystation on the road to conservative restoration. They thought they were seeing the wave of the future, a region that at long last had shaken off the race issue, freeing its politics for realignment along economic lines. Surveying the scene in 1976, Jack Bass and Walter DeVries wrote: "The political liberation of southern Blacks, important as it is, may be of less significance than the liberation of southern whites...The South retains some distinctive regional qualities, but it has joined the nation's political mainstream" (p. 407). Alexander Lamis published the first edition of The Two-Party South in 1984, opening with the observation that "by the early 1970s...one could discern a distinct lessening of racial tension in the region...the altered racial environment contributed to the development of two-party politics" (p. 5), and concluding: "Party competition has now firmly settled into the region" (232). These statements were not revised in the edition of 1988, which noted that "the most striking feature of the recent period is continuity with the patterns described in the original edition" (p. x). Writing in 1990, political scientist Laurence W. Moreland held that "there is no evidence to suggest that a new one-party Republican South looms in the future." 53 Even in the decade following the transformative election of 1994, the eminent scholars Earl and Merle Black wrote: "If the old solid Democratic South has vanished, a comparably solid Republican South has not yet developed. Nor is one likely to emerge." ${ }^{4}$

\footnotetext{
${ }^{52}$ Hood et al, The Rational Southerner, p. 94; McKee, Republican Ascendancy, p. 15; Feldman, Painting Dixie Red, p. 319. The need to build the party from the top down is stressed by Aistrup, The Southern Strategy Revisited. The concluding quotation is from Kevin Drum, Mother Jones, November 25, 2015 (on line).

${ }^{53}$ Moreland, "Ideological and Issue Bases of Southern Parties," p. 131. John Van Wingen and David Valentine were even more emphatic: "Absolutely nothing in the data indicates that the Republicans will soon shed their minority standing" ("Partisan Politics: A One-and-a-Half, No-Party System," p. 144).

${ }^{54}$ The Rise of Southern Republicans, p. 3. Two years later, John A. Clark and Charles L. Prysby wrote: "In almost every [southern] state, both parties have a reasonable chance of winning important statewide contests..." (Southern Political Party Activists, p. 3).
} 
An analysis of patterns of party identification among native white southerners in the early 1990s confirmed the emergence of a class-based partisanship that had been missing in earlier decades: higher status individuals favored Republican identification, while those whites who remained Democrats had "tendencies similar to whites in the rest of the nation: older, Catholic, union members, blue-collar, working-class, less educated, and less affluent." ${ }_{55}$ An update ten years later confirmed the shift towards "normal," class-based polarization among white southerners, and the "movement away from race as the sole issue of importance to Southern voters." ${ }^{56}$ In their 2006 reassessment of postwar southern political history, political scientists Byron Shafer and Richard Johnston found that southern white party identification was tightly linked to social class, refuting the notion that the politics of race provided a "reliable and consistent contribution" to Republican ascendancy. ${ }^{57}$

To be sure, from the information in Figures $4 \mathrm{a}$ and $4 \mathrm{~b}$ alone, one could not distinguish an old-line segregationist Democrat from a new-breed progressive. In fact, the 1970s South saw a wave of "New South" Democratic governors, including such prominent and successful figures as Reubin Askew of Florida, Dale Bumpers and David Pryor of Arkansas, Jimmy Carter and George Busbee of Georgia, Edwin Edwards of Louisiana, and John West of South Carolina. All were moderates by national standards, and all had similar programs to replace the divisive race issue with unifying support for economic development, through education and other infrastructure investments. Nor was this a one-generation affair. The first wave of the 1970s was succeeded by a second wave in the 1980s, featuring names such as Bob Graham of Florida, Dave Treen of Louisiana, William Winter of Mississippi, Richard Riley and Carroll Campbell of South Carolina, Chuck Robb of Virginia, and Bill Clinton of Arkansas. Historian Gordon Harvey writes that since 1970, every southern state except Alabama has elected at least one New South governor. ${ }^{58}$

The picture was much the same for southern Democrats in the U.S. Senate. Not only did their numbers remain high through the 1980s, but their average ADA liberalism ratings

\footnotetext{
${ }^{55}$ Nadeau and Stanley, "Class Polarization in Partisanship," p. 915.

${ }^{56}$ Nadeau et al, "Class, Party and South/Non-South Differences," p. 61.

${ }^{57}$ The End of Southern Exceptionalism, pp. 177-185.

${ }^{58}$ Harvey, A Question of Justice, p. 173. See also Black, Southern Governors and Civil Rights, and Sanders, Might Peculiar Elections.
} 
continued to rise during this period. Well-known names include former governors Hollings, Bumpers and Pryor, plus Ralph Yarborough of Texas, and Albert Gore Sr. of Tennessee. Yarborough and Gore were defeated for re-election in 1971, largely over the Vietnam War rather than race or economics. But only Gore lost to a Republican, and in that case the seat was retaken six years later by progressive Democrat Jim Sasser, who served until 1995. Clearly these experienced politicians did not believe they were out of step with their constituencies..$^{59}$

\section{Race, Economy and Realignment in the South}

If this characterization of the two-party South is accurate, the obvious question is why the region's voters moved so decisively to the right from the mid-1990s onward. Broadly speaking, historians and social scientists have offered two main interpretations of realignment: the first emphasizes race and racial backlash, including the emergence of a new, "coded" language reframing issues in ostensibly race-neutral terms; the second argues that the main driving force has been economic development, by which is meant the shift of population into suburbs, attracted by conservative positions on economic issues such as taxes and government spending. Other accounts feature innovations in political rhetoric and outreach, such as the mobilization of evangelical Christians on issues such as abortion and homosexuality; but the question of racialized appeals versus economic interests persists even in this broader frame..$^{60}$

A reasonable person can believe that there is truth in both interpretations. The superficial race-neutrality of modern southern political discourse cannot be taken at face value. Ilyana Kuziemko and Ebonya Washington find that holding racially conservative views is the single strongest predictor of the shift in southern white party identification between 1958 and 1980 - a period when regional survey responses on race questions were moving towards national norms. ${ }^{61}$ Although the openly racist rhetoric of earlier times was no longer acceptable, unobtrusive measures of racial attitudes - designed to remove the effects of social desirability - pointed to

\footnotetext{
${ }^{59}$ Shaffer, "Ideological Trends Among Southern U.S. Democratic Senators;" Fleisher, "Explaining the Change in Roll-Call Behavior of Southern Democrats."

${ }^{60}$ The literature is too large for a comprehensive listing, but a convenient introduction may be found in the essays by Carter and by Shafer and Johnston in Maxwell and Shields (eds.), Unlocking V.O. Key Jr. Leading statements of the two positions are Carter, From George Wallace to Newt Gingrich; and Shafer and Johnston, The End of Southern Exceptionalism. The most recent contribution, Maxwell and Shields, Long Southern Strategy, depicts an ongoing strategy by Republicans to appeal to white southerners, by adopting themes related to race, feminism, and religion. The authors write: "The economic masks the racial, so much so that many do not even see it" (p. 91).

${ }^{61}$ Kuziemko and Washington, "Why Did the Democrats Lose the South?"
} 
distinctly higher levels of racial prejudice in the South than in the non-South even in the 1990s. ${ }^{62}$ Political scientists Nicholas Valentino and David Sears find a strong association between southern ideological conservatism and "modern" or "symbolic" racial attitudes, reflected in beliefs that Black disadvantages are caused by poor work ethic, or that Blacks make excessive demands and get too many concessions from government. ${ }^{63}$ At times the racial appeals were not even disguised, as in the blatant images deployed by Jesse Helms during his North Carolina senatorial campaigns against Harvey Gantt in 1990 and 1996.

The pervasiveness of southern race consciousness, however, does not imply that economic considerations did not matter. V. O. Key famously wrote: "Whatever phase of the southern political process one seeks to understand, sooner or later the trail of inquiry leads to the Negro." But the very next sentence reads: "Yet it is far from the truth to paint a picture of southern politics as being chiefly concerned with the maintenance of the supremacy of white over Black." ${ }_{64}$ That disclaimer is as apt for later decades as it was in the Jim Crow era. Whatever their racial attitudes, the median southern white voter cast a ballot for a moderate-toliberal Democrat until 1994. Veteran observers of southern politics saw this break as a discontinuity that could not have been foreseen even a few years before. Alexander Lamis, for example, in a sequel to his earlier books on the two-party South, stressed that the trends down to 1990 did not foretell the Republican surge. ${ }^{65}$ Writing two decades later, Charles Bullock III remarked: "After seven elections in which between 45 percent and 55 percent of whites voted Democratic, support fell [in 1994] to barely a third and has yet to rise." 66

There are no official records of voter choices by race, and the archival inventory of exit polls for non-Presidential elections is not complete. But the basic mathematics of southern electoral demography confirms the truth of Bullock's statement, in light of the facts that the Black share of state electorates was essentially stable from 1980 to 2014 (ranging between 15 and 30 percent in most states), and Black voters remained solidly Democratic, playing no part in the realignment process. Throughout the period, the share of Hispanic voters was too small to

\footnotetext{
${ }^{62}$ Kuklinski, Cobb and Gilens, "Racial Attitudes and the "New South."”

${ }^{63}$ Valentino and Sears, "Old Times There are not Forgotten."

${ }^{64} \mathrm{Key}$, Southern Politics in State and Nation, p. 5.

${ }^{65}$ Lamis, Southern Politics in the 1990s, pp. 30-32.

${ }^{66}$ Bullock "Introduction," in Bullock and Rozelle (eds.), The New Politics of the Old South, p. 14.
} 
have political significance outside of Texas and Florida. The implication is that Figures 4a and $4 \mathrm{~b}$ understate the discontinuity of the 1990s, which was entirely a white voter phenomenon. Available exit polls confirm this general picture. For Senatorial elections in the 1980s, for example, Democratic incumbents were comfortably returned to office with biracial majorities, while open-seat competition for white votes was essentially even. ${ }^{67}$

What happened between 1990 and 1994 to precipitate such a drastic political response? Gaddie and Hoffman observe that unlike previous "critical realignment" elections, the 1994 voter revolt defies easy categorization in terms of issues or events, even in the South: "The potential culprits in this mystery, in short, are numerous...the elections of the 1990s might be characterized as realignment by a hundred cuts..." ${ }^{68}$ Many observers point to the Congressional redistricting measures of the early 1990s, which created Black-majority districts and allegedly drove the parties to extremes. But statewide elections displayed the same trend shift at the same time. Political scientists Adam Bonica and Gary Cox argue that the prospect of Republican control of the House (for the first time since the 1950s) focused the attention of activists, donors, and party leaders on the battle for majority status, a process that may have had spillover effects on statewide elections. ${ }^{69}$ But if so, what was the substantive content of this intensified mobilization? Lamis and others emphasize the personal unpopularity of President Clinton in 1994, reflecting an apparently successful Republic effort to "nationalize" House elections in that year. According to Gary Jacobsen, "fully 44 percent of [sampled] white southern males said that their House vote was a vote against Clinton." 70 But Clinton and his running mate Al Gore were both southerners, who ran about even in the South against Bush and Quayle in 1992. What could have changed so dramatically in just two years?

It seems to have escaped attention in this literature that much of the South experienced wrenching economic dislocation at precisely this time, as the manufacturing industries that had

\footnotetext{
${ }^{67}$ Black and Black, Rise of Southern Republicans, Figure 4.3.

${ }^{68}$ Gaddie and Hoffman, "Critical Events in Southern Politics," p. 36.

69 "Ideological Extremists in the U.S. Congress." Bonica and Cox do not particularly emphasize redistricting, though it could have contributed to the prospects of a Republican House majority. Abramowitz et al, however, show that the decline in party competition within districts cannot be explained by redistricting ("Incumbency, Redistricting, and the Decline of Competition in U.S. House Elections").

70 Jacobsen, "The 1994 House Elections in Perspective," p. 208. Increasing alignment between southern presidential and gubernatorial voting is documented by political scientist Daniel Hopkins, "especially after 1994" (Increasingly United States), pp. 47-48.
} 
formed the core of the regional economy began their historic descent in response to import competition. Figure 5 conveys some sense of the magnitude of employment losses. North Carolina lost the most jobs, mainly because it was the largest manufacturing state. But in proportionate terms, the patterns were similar and the falloffs nearly as great in all the southern states. Research by David Autor, David Dorn, and Gordon Hanson documents the geographic concentration of trade-exposed local labor markets in these states. ${ }^{71}$

Figure 5. Manufacturing Employment by State, 1952-2017
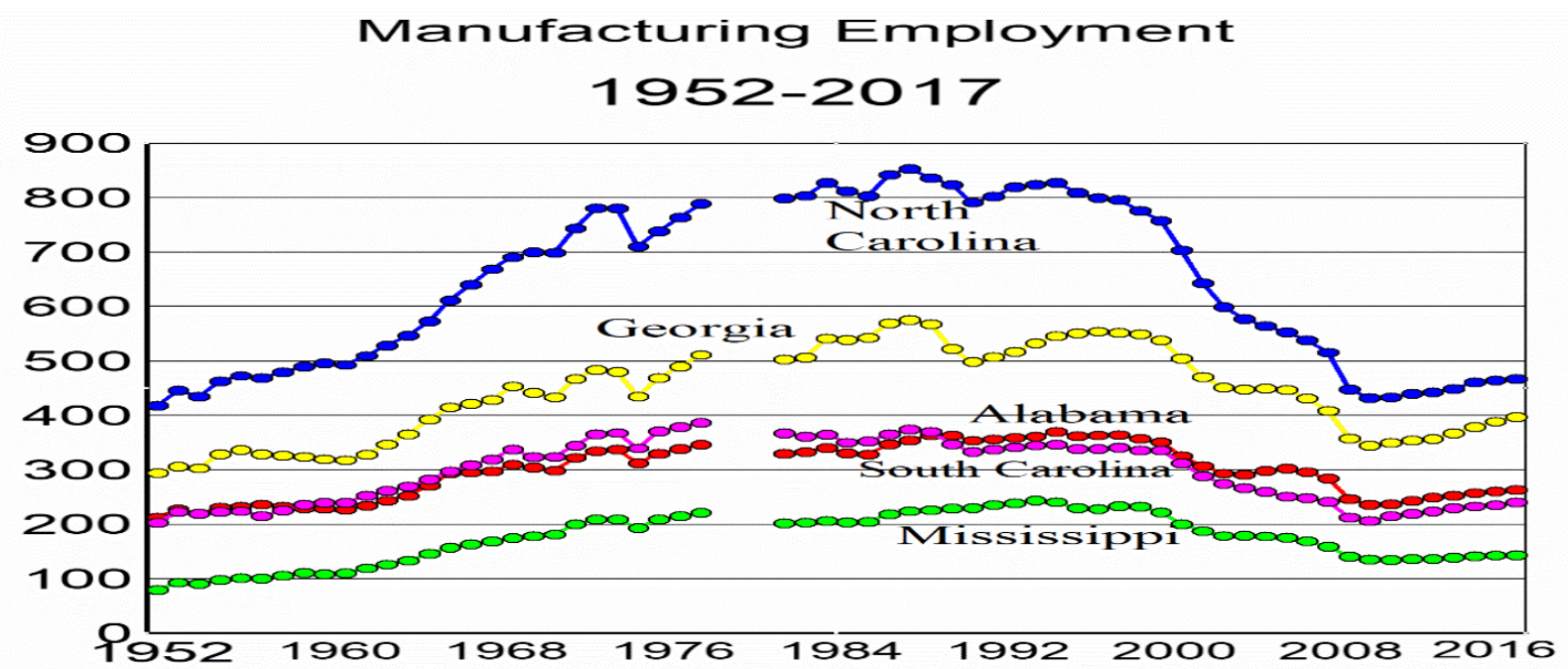

SOURCE: Bureau of Labor Statistics

Could this global economic restructuring have affected regional partisan voting? Indeed, it was front and center. One highly visible object was NAFTA, enacted in November 1993 with vigorous backing from President Clinton, implemented January 1, 1994. Although supported by some parts of the industry, NAFTA was strongly opposed by workers and unions in textile areas (as well as the industrial Midwest)? The origins of the pact were bipartisan, but Clinton took most of the blame, and Democrats voting in favor suffered badly at the polls in 1994. The most famous example was Tom Foley of Washington, the first House speaker to lose his seat since the Civil War. But southern Democrats supporting NAFTA were also hard hit. Those who lost seats included six-term incumbent Buddy Darden of Georgia and David Price of North Carolina.

\footnotetext{
${ }^{71}$ Autor, Dorn, and Hanson, "The Geography of Trade and Technology Shocks in the United States,” pp. $222-223$.
} 
Rising star Clete Johnson of Georgia lost his re-election bid by 31 percentage points, the largest margin of the year. A handful of other incumbents barely survived.

Of more direct relevance for Textiles and Apparel was the 1994 Agreement on Textile and Clothing, negotiated as part of the WTO's Uruguay Round. The agreement phased out the import quotas of the Multi-Fibre Arrangement (MFA) over the ten-year period 1994-2004. The two issues interacted, when Clinton sent letters to textile and apparel state representatives shortly before the vote on NAFTA, promising that an extended phase-out of fifteen years would be secured. A month after the NAFTA vote, U.S. negotiators accepted the ten-year plan. Figure 6 shows that employment in these sectors, which had been drifting downward through the 1980s, began a precipitous decline in 1994, in every southern textile state. Although Textiles and Apparel comprised less than ten percent of U.S. manufacturing employment in 1990, they accounted for nearly one-third of the employment contraction between 1990 and $2003 .^{72}$

Business leaders, workers and their unions clearly understood the importance of import quotas to the industry's survival. Maintaining them was the object of lobbying and grass-roots mobilization for decades. A landmark of sorts was the Textile and Apparel Enforcement Act of 1985, passed by both houses and vetoed by President Reagan. As the vote to override the veto neared, thousands of workers bombarded their representatives with pleas for support. Many writers bolstered their case by pointing out that in the wake of the Civil Rights movement, textiles and apparel now provided employment for women and minorities in large numbers. Within five days of the override vote, Reagan announced the successful negotiation of a new, tougher MFA that expanded coverage to fibers such as ramie, linen and silk blends and would prevent "destructive import surges." The override motion was subsequently defeated, but textile and apparel workers had accomplished their main goal. Despite Republican support for free trade in principle, highly mobilized textile workers received more political responsiveness from the Reagan administration in the 1980s than from Bill Clinton in the 1990s. ${ }^{73}$

\footnotetext{
${ }^{72}$ U.S. Department of Labor, Report to Congress, pp. 35-37.

${ }^{73}$ Minchin, Empty Mills, pp. 84-85. This paragraph draws upon Minchin, esp. pp. 57-85, 91-117.
} 


\section{Figure 6}

\section{Textiles \& Apparel Employment $1961-2016$}

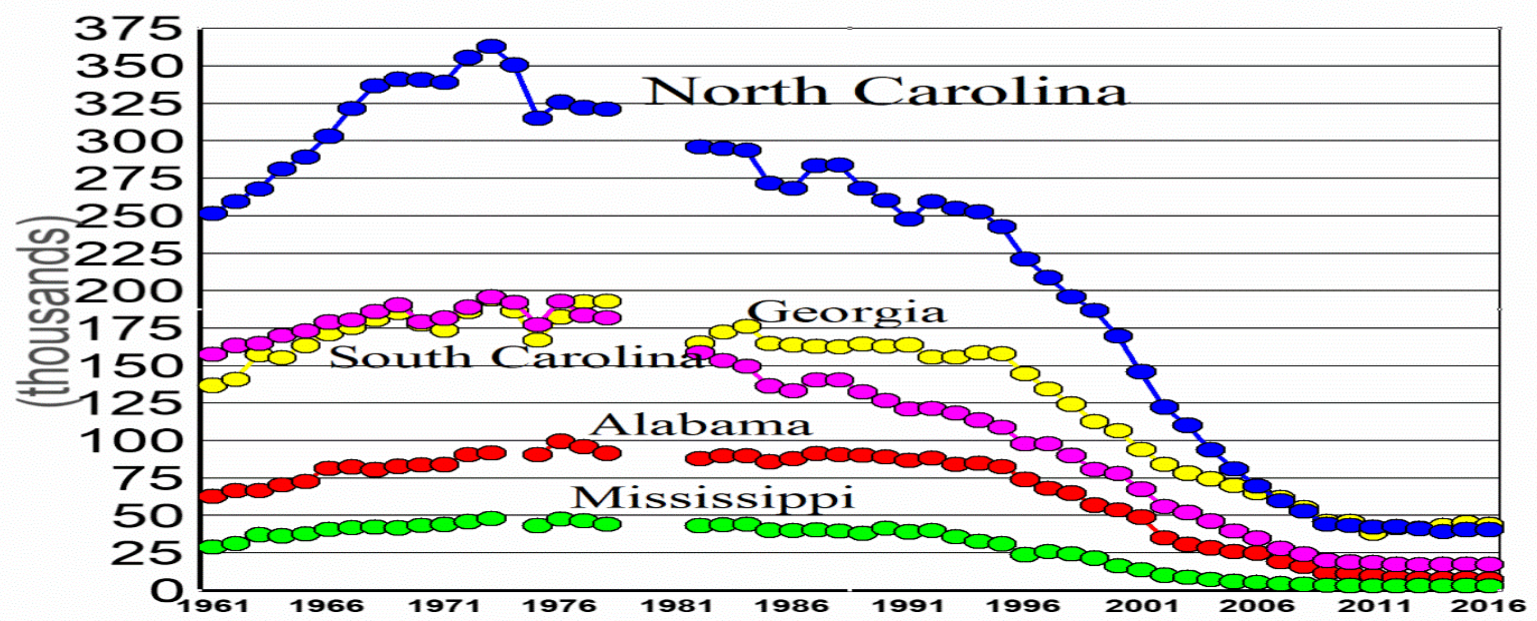

SOURCE: Annual Survey of Manufactures.

As events unfolded, the worst fears of the trade liberalization critics were realized. Over the next fifteen years, employment fell far more rapidly than industry analysts expected. ${ }^{74}$ Most economic studies of job displacement identify the 2001 entry of China into the WTO as the key turning point. ${ }^{75}$ But in the South, the break came earlier: in the leading textiles-and-apparel states, more factory jobs were lost before 2001 than after. Economists Shushanik Hakobyan and John McLaren use census data for 1990 and 2000 to identify the effects of NAFTA, finding dramatically lowered wage growth for blue-collar workers and for affected localities. ${ }^{76}$ NAFTA may have been a contributing factor, in that textile and apparel imports from Mexico surged between 1994 and 2000 (before being displaced by Chinese imports). But the demise of the MFA precipitated rapid growth of textiles and apparel imports from many other countries as well, including Pakistan, Bangladesh, Vietnam, Indonesia and Canada. ${ }^{77}$ The expansion of

\footnotetext{
${ }^{74}$ Mittelhauser, "Employment Trends in Textiles and Apparel," predicted in 1997 that the industry would still employ 1.3 million workers in 2005. The true figure was less than 0.5 million. As late as 2004, the BLS projected "fairly modest changes" over the decade 2000-2010 (U.S. Department of Labor, "Report to Congress," pp. 46-51. ${ }^{75}$ Autor et al, "The China Syndrome;" "The China Shock." Congress voted to approve Clinton's proposal to award Permanent Normal Trade Relations status to China in 2000.

${ }^{76}$ Shushanik Hakobyan and John McLaren, "Looking for Local Labor-Market Effects of NAFTA." The authors report that the nine most vulnerable conspumas were all in Georgia and the Carolinas (Table 3).

${ }^{77}$ U.S. International Trade Administration. Office of Textiles and Apparel (OTEXA). US General Imports by Country.
} 
Chinese imports after 2001 added another inflection point to the downward spiral, helping to explain why early projections underestimated the speed of change so severely.

To be sure, the South was a full participant in the boom of the late 1990s. But that burst of prosperity had little relevance for most displaced mill workers. Detailed studies by the BLS show that former textile workers typically experienced long bouts of joblessness and found new jobs only at substantially reduced pay and benefits, especially health insurance. These effects are confirmed by Autor and his co-authors, who find that workers who lost jobs to Chinese imports experienced more unemployment, lower labor-force participation, lower wages, and little sectoral or geographic mobility. ${ }^{78}$ These losses were of course not exclusive to the South, but evidence from Trade Adjustment Assistance certifications confirm that states most heavily invested in low-wage manufacturing had the largest shares of their workforces affected by trade, southern states leading the lists. ${ }^{79}$ Reports in recent years of a "comeback" for the domestic textiles industry have little relevance for most former textile workers: the new jobs are a small fraction of previous levels and the required skill levels far higher. ${ }^{80}$

This account should not be understood as a suggestion that switching party allegiance was a rational response to economic distress, nor that displaced textile workers were the cutting edge of southern Republicanism. The argument instead is that the political-economic basis for a biracial coalition was undermined by deindustrialization. The campaign to protect textiles and apparel jobs was a biracial group with a common economic goal, in a setting that could not be stigmatized in racial terms. By the 1990s, nearly 30 percent of nondurable manufacturing employees in leading textile states, and about 35 percent of operatives, were Black. Layoffs were roughly proportionate to this racial composition, implying that the majority of job-losers were white. ${ }^{81}$ Through their unions as well as through impromptu political groups, the races cooperated on appeals to preserve jobs, just as they had on campaigns for industrial development

\footnotetext{
${ }^{78}$ Autor, Dorn, and Hanson, “The China Syndrome,” pp. 2141-2151.

${ }^{79}$ Kevin Schaul and Dan Keating, “The States Most Threatened by Trade," The Washington Post August 22, 2014. Survey studies show that opposition to free trade is strongest among low-skilled workers: Scheve and Slaughter, Globalization and the Perceptions of American Workers; Scheve and Slaughter, "What Determines Trade Policy Preferences? See also Blonigen, "Revisiting the Evidence on Trade Policy Preferences."

${ }^{80}$ Minchin, Empty Mills, pp. 222-233. Examples of textile "comeback" stories include Stephanie Clifford, "U.S. Textile Plants Return, with Floors Largely Empty of People," New York Times September 19, 2013; Marsha Mercer, "Textile Industry Comes Back to Life, especially in South," USA Today February 5, 2014.

${ }^{81}$ Equal Employment Opportunity Commission, Job Patterns for Minorities and Women in Private Industry, 1990.
} 
in earlier decades. The South was never highly unionized, but labor organizations punched above their weight in political contests, especially with working-class voters. Deindustrialization decimated union membership as well as factory jobs (Figure 7). Once the structural basis for that coalition was removed, it was only to be expected that the attractiveness of alternative appeals was a function of regional culture, including but not exclusively racial attitudes.

In the circumstances, it is hardly surprising that Black and Black found that low-income white southerners "displayed little working-class solidarity in their partisan preferences" in 1996, more than half preferring Republicans on the basis of religion, abortion and gun owner's rights as well as opposition to racial preferences. What deserves emphasis is that this pattern of nonclass-based voting by white southerners was a change from the previous generation. Texeira and Abramowitz show that Democratic identification among lower socioeconomic white southerners fell dramatically in the 1990s, and even more dramatically afterward: "Class differences in party identification have not disappeared but are considerably smaller than they were thirty or forty years ago."82 In an update to their 2006 book, even Shafer and Johnston acknowledge a post2000 Republican shift among low-income southern white voters, "the people who for forty years rejected the new southern Republican party." 83

${ }^{82}$ Texeira and Aramowitz, "The Decline of the White Working Class," esp. Figure 2.

${ }^{83}$ Black and Black, Rise of Southern Republicans, pp. 263-266; Shafer and Johnston, "Partisan Change in the PostKey South," in Maxwell and Shields (eds.), Unlocking V.O. Key, Jr., pp. 168-170. Shafer and Johnston use decadal averages (i.e., 1980s, 1990s, 2000s) in their analysis, so the timing of the shift they describe cannot be determined with precision. But their case that southern working-class Republicanism was late in coming is persuasive. 


\section{Figure 7}

\section{Union Density Textile States \\ $1964-2018$}

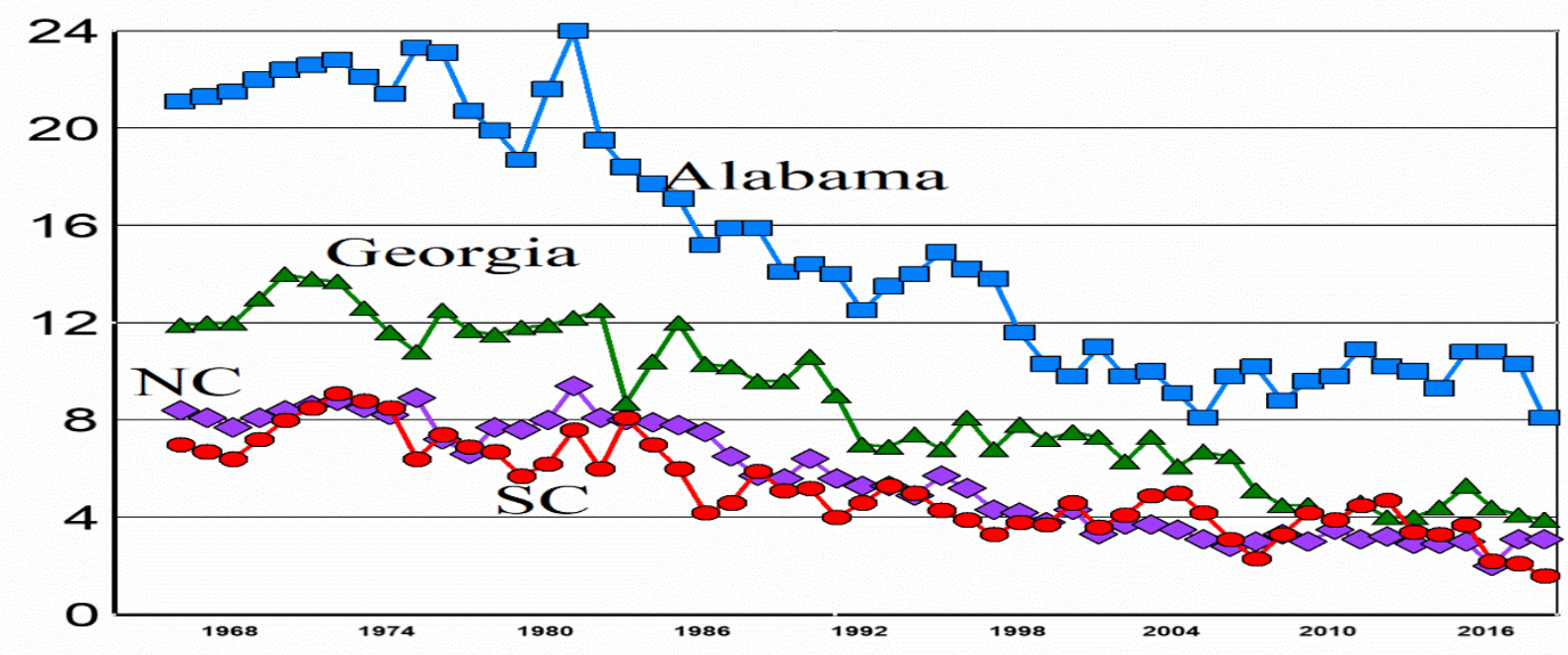

Source: Hirsch, McPherson, Vroman, "Union Density Estimates by State"

Across broad swaths of the region, deindustrialization and economic stagnation have been the dominant facts of life for white southerners in recent decades. The travel writer Paul Theroux spent three years on the road in the South and reported:

...if there is one experience of the Deep South that stayed with me it was the sight of shutdown factories and towns with their hearts torn out of them, and few jobs. There are outsourcing stories all over America, but the effects are stark in the Deep South...I found towns in South Carolina, Mississippi, Alabama, and Arkansas that looked like towns in Zimbabwe, just as overlooked and beleaguered. ${ }^{84}$

This essay's modest proposal is that the change in southern white voting behavior was associated with this deterioration in economic performance.

\section{Consequences: Racial Polarization}

Whatever the combination of economic, ideological, and racial motivations for the southern swing to the Republican Party, the effect was to exacerbate racial polarization in southern political life. Increased racial polarization in Presidential voting has been documented

\footnotetext{
${ }^{84}$ Paul Theroux, “The Hypocrisy of 'Helping' the Poor," New York Times October 2, 2015
} 
by three MIT faculty members in two studies prepared in connection with judicial review of the Voting Rights Act. ${ }^{85}$ The authors compare states covered by the Voting Rights Act (primarily southern) with those uncovered or only partially covered, using exit polls from Presidential elections since 1984. The gap between Black and white voters (as well as between Hispanic and white voters) was always higher in the covered states, and this regional contrast increased over time, with a spurt between 2004 and 2008 presumably associated with the candidacy of Barack Obama. Regional differences in polarization by these measures increased again between 2008 and 2012. Although partisanship in Presidential votes is more easily tracked over time, the evidence suggests that similar patterns held in state and district voting. In one sense we already knew this, because the southern Republican voters had been virtually all-white throughout the post-Civil Rights era, while Democratic voters were biracial. ${ }^{86}$

As Republican majorities have emerged in the southern states, many state legislatures have taken on attributes of one-party regimes, with manifest consequences for racial relationships. Table 3 shows that prior to 1994, Black legislators were in the majority party in virtually all southern state legislatures. The numbers of Black legislators actually increased between 1992 and 2010, but many lost majority status following the 1994 midterm elections. The decisive blow came with the 2010 midterms, after which 95 percent of southern Black state legislators had minority status. (Both houses of the Arkansas legislature became majorityRepublican in 2014, completing the cycle.) Although Republicans made gains outside of the South during these years as well, more than half of non-southern Black state legislators belonged to the majority party throughout the period. In Alabama, Florida, , Mississippi and Georgia, more than half the Democratic state legislators were Black by 2010, constraining the party's ability to appeal to white voters. ${ }^{87}$

An immediate consequence was to end what had been a steady advance of Black legislators into leadership positions. In Georgia, the Legislative Black Caucus was highly effective in the 1990s; by 1999-2000, LBC members chaired four committees in the house and five in the senate, including the powerful Rules Committee. The loss of Democratic control in

\footnotetext{
${ }^{85}$ Ansolabehere, Persili and Stewart, "Race, Region, and Vote Choice in the 2008 Election;" "Regional Differences in Racial Polarization in the 2012 Presidential Election."

${ }^{86}$ See for example the chart for Senatorial elections in Black and Black, Rise of Southern Republicans, p. 135.

${ }^{87}$ Bositis, Resegregation in Southern Politics? Table 3.
} 
2004 greatly diminished African American influence, reducing them to token chairmanships of minor committees. African Americans gained several chairmanships in the Florida Senate between 1988 and 1996, but all of these were lost with the new Republican majority in 1996. In North Carolina, African Americans held powerful committee chairmanships and leadership positions in both houses, progress that largely ended with the Republican majorities of 2012. In South Carolina: "With the loss of control by Democrats [in 2002], African American legislators have little prospect of playing significant roles in the South Carolina legislature, though Black clout in the Democratic caucus is enhanced." 88

Although earlier studies reported that greater Black representation tended to move policy outcomes towards the preferences of Black voters, more refined analysis finds that these effects are vitiated when the parties are highly racialized and the opposite party is in power - as in most southern states in the $21^{\text {st }}$ century. ${ }^{89}$ Even where the Democrats were extremely conservative, the change in party control has had a major impact on Black representation. In Alabama, threedecade state senator Hank Sanders lost the chairmanship of the Finance and Taxation Education Committee when Republicans gained the majority in 2010. Sanders had used his position to increase the level and equitability of state resources for education and other forms of infrastructure, but he and other Black legislators were then almost completely excluded from major decisions. According to Auburn political scientist Gerald Johnson: “There's been a total collapse of Madisonian Democratic government. There's no debate, no compromise, and no minority participation - and by minority, I mean Democratic or African American."90

This is not to suggest that the South has returned or is close to returning to the pre-Civil Rights era in its political race relations. Black influence in state legislatures may be limited, but overall Black political participation remains high, and representation in municipal and county offices provides a considerable measure of self-determination and racial equity. Republican control of state government has not prompted mass dismissals of Black public sector employees. Some observers believe that the South has settled into a New Racial System, in which separate

\footnotetext{
${ }^{88}$ Bullock and Gaddie, Triumph of Voting Rights, pp. 93, 177, 207-208; Menifield and Shaffer, Politics in the New South, pp. 55-59, 82-85.

${ }^{89}$ Preuhs, "The Conditional Effects of Minority Descriptive Representation."

${ }^{90}$ Zengerle, "The New Racism."
} 
political spheres are largely respected, just as the dualistic system of higher education has essentially been recognized by the courts, with biracial approval. ${ }^{1}$

This new regime may have some virtue in maintaining racial peace, but there are at least two major drawbacks. One-party dominance creates both an incentive and an opportunity to limit access to voting in order to maintain partisan advantage. When the parties are racially polarized, "partisan advantage" has inescapable racial implications. In an exhaustive review of the voting rights record since 1965, J. Morgan Kousser shows that proven violations have been overwhelmingly concentrated in the same jurisdictions covered by the triggering formula set down in $1970 .{ }^{92}$ These largely southern states have led the way in measures making registration and voting more difficult for low-income voters, particularly since the Supreme Court's ruling in Shelby County v. Holder (2013) invalidating the VRA coverage formula. The second drawback is that policies adopted by the new Republican administrations do not appear to reflect the interests or preferences of a majority of state residents.

\section{Consequences: Support for Education}

If the transition to Republican voting were constrained primarily by organizational inertia and switching costs, then we would not expect to find that attainment of Republican control led to substantive changes in public policy choices. If southern Democrats were merely those conservatives who had not yet found it convenient to relabel themselves, why should their votes on policy issues change when the relabeling actually occurred? Yet policy continuity in southern states is not what we see. The first major disrupter was the Voting Rights Act itself. With the ascendance of competitive two-party politics, a cohort of progressive New South governors (mainly Democrats) led campaigns to upgrade state school systems, escaping divisive racial issues to mobilize broad support for a pro-growth agenda that would benefit all residents.

South Carolina is a case in point. As of 1971, the state's school chronically underfunded school system had long suffered dropout rates above 50 percent. Because teacher salaries fell 25 percent below the national average, more than half of recent teacher education graduates left to work in other states. After defeating a segregationist opponent in 1970 with the help of Black

\footnotetext{
${ }^{91}$ Browder, The South's New Racial Politics, pp. 81-95. Browder is a former Alabama legislator, secretary of state, and Democratic congressman.

${ }^{92}$ Kousser, "Do the Facts of Voting Rights Support Chief Justice Roberts' Opinion in Shelby County?"
} 
voters, Governor John West launched a major effort to reduce dropout rates, particularly among Black students. Increased state spending between 1965 and 1975 was largely driven by surging state revenues rather than higher taxes (reflecting the booming Sun Belt economy), but the share of the budget allocated to education also sharply increased. At the end of West's term in office, the conservative newspaper Columbia State gave the governor credit for "major advances in the economy and race relations, concluding: "We much prefer this New South thinking and goals to the moonlight, magnolias, and political hell-raisin that characterized the old Solid South." Although West was unable to change the state's system of school finance, his example paved the way for Governor Richard Riley's more sweeping Education Improvement Act of 1984.93

Similar patterns prevailed over much of the post-Civil Rights South. Figure 8 displays per pupil spending on K-12 education for seven southern states from 1948 to 2016, as a fraction of the national average. Despite fears that school integration would weaken support for public schools, Georgia, North Carolina, South Carolina and Virginia actually accelerated their progress after 1965. Only in Alabama and Mississippi did school spending decline during the turbulent years 1966-1970, after which these states too resumed the trend towards convergence on the national average. Some of the increase reflected new federal support for public schools in lowincome areas, but most of it was the result of new state policy priorities and economic growth.

\footnotetext{
${ }^{93}$ This paragraph is drawn from Harvey, A Question of Justice, pp. 138-168, 173.
} 


\section{Figure 8}

\section{Per Pupil Spending as \% US Average}

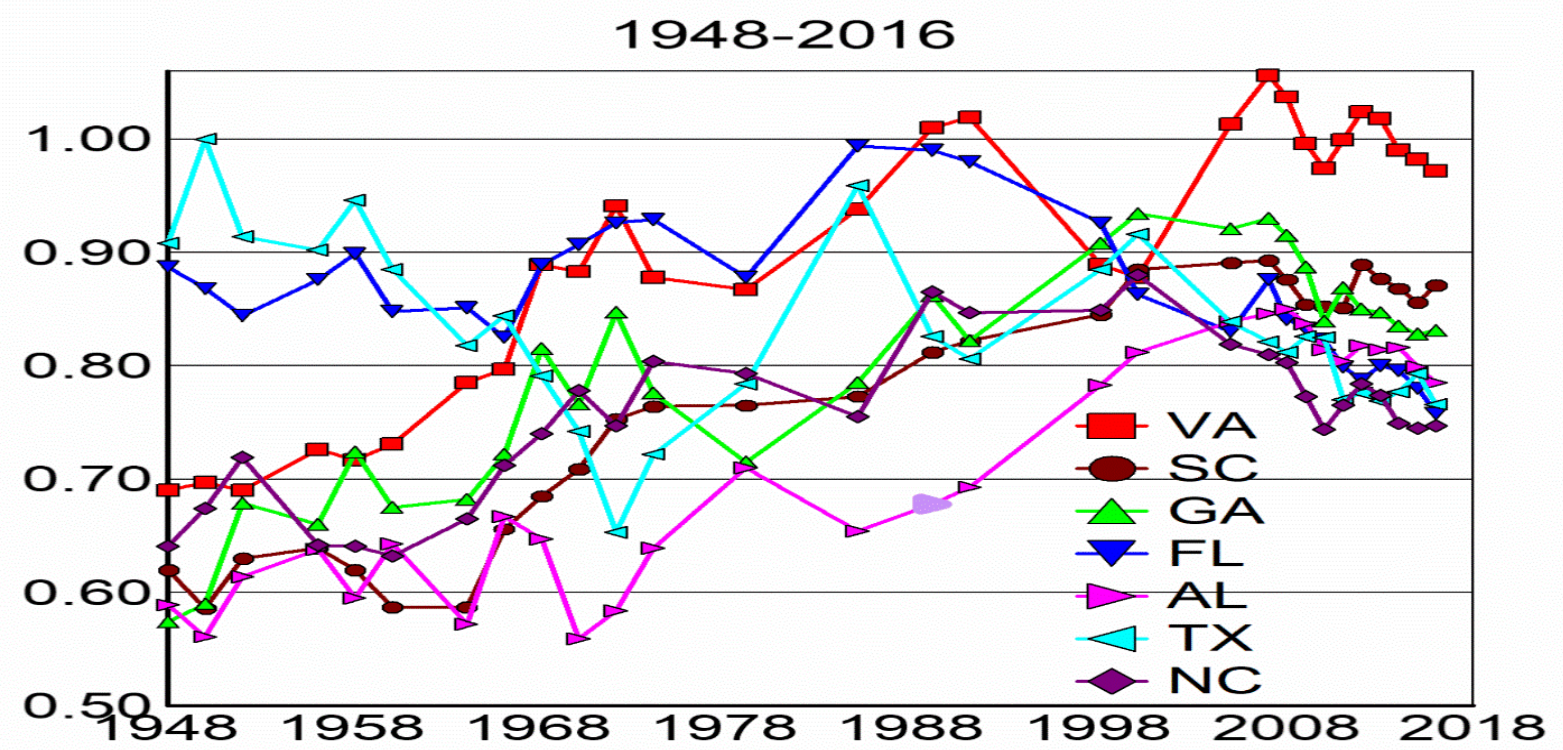

Source: National Center for Education Statistics, Digest of Education Statistics, various years

In Alabama, Governor Albert Brewer (who assumed office after the death of Lurleen Wallace) steered a major educational reform package through the state legislature in 1969, saying "Our problem is not race [but education]." When funds ballooned in the Special Education Trust Fund, Brewer allocated them to teachers' salaries and capital improvements in the schools. Brewer was defeated by George Wallace in 1970, but an atmosphere of expansionary optimism continued into the 1980s, culminating in the Education Reform Act of 1984. ${ }^{94}$ Sarah Reber shows that rising expenditures in Louisiana were instrumental in facilitating school desegregation, as the legislature allocated additional funding to districts where whites would be particularly affected..$^{95}$

Even Mississippi, long the most educationally backward state, belatedly got into the reform act. The state's compulsory education law, repealed in 1956 during the desegregation crisis, was reenacted in 1977. Gubernatorial candidate William Winter ran on an education

\footnotetext{
${ }^{94}$ Harvey, A Question of Justice, pp. 41-63; Rudder, "Educational Reform in Alabama."

${ }^{95}$ Reber, "From Separate and Unequal to Integrated and Equal?"
} 
reform platform in 1979 and got most of his plan through the state legislature in 1982. With biracial support, state funding for kindergarten was introduced, teacher pay increased, and performance-based accreditation instituted. Performance gains from a new assistant-teacher program were said to be "one of the most visible signs of educational progress in the state." 96 Mississippi was the last state to provide funding for kindergarten; every other state in the former Confederacy enacted this reform between 1968 and $1978 . .^{97}$

The resurgence of southern public schooling did not survive the counter-revolution of partisan realignment. Figure 8 shows that progress toward national spending levels was halted or reversed in every state except Virginia. In Alabama and Mississippi, the reform impulse ended in the late 1980s, predating the shift in partisan control. Elsewhere the reversal largely tracked the advent of Republican governors and state legislative majorities. Cutbacks were particularly severe in Florida, Georgia and North Carolina, reversing decades of relative progress. Florida and Texas, having distinctive political histories, were well ahead of other southern states in earlier decades. But these states joined the budget-cutting trend in the 1990s, ending the period in the middle of the regional pack.

The transition to Republican majorities may have been the proximate cause of these spending cuts, but an important background factor - perhaps jointly contributing to both developments - was the fact that a majority of public school students were now people of color. This milestone was reached in 2007, prior to the Great Recession, but the trend had been underway for at least two decades. Unlike many urban school districts, this compositional shift was not driven primarily by white flight into private schools, but by the influx of Hispanics, whose share of the total increased from six percent in 1978 to more than 20 percent in 2008. Although the broad trends were similar nationwide, the South is the only region of the country to have a majority of both low-income students and students of color in the public schools. ${ }^{98}$

Southern institutions of higher education fared little better. In a turn-of-the century assessment of the South's progress, historian Thomas G. Dyer called attention to the

\footnotetext{
${ }^{96}$ Jenkins and Person, "Educational Reform in Mississippi," pp. 82-107; Bolton, The Hardest Deal of All, p. 217.

${ }^{97}$ Cascio, "Maternal Labor Supply," Table 1.

${ }^{98}$ Southern Education Foundation, A New Diverse Majority, pp. 5, 10-1114-15. See also SEF, A New Majority (2007), with updates in 2013 and 2015.
} 
extraordinary rise in the size and quality of the region's research universities from the 1960s through the 1990s. The growth had many sources, but "most important was the rolling of unprecedented large sums of tax money into public higher education from the late 1950s into the 1990s, in complete contrast to the pattern earlier in the century." 99 Dyer speculated ruefully that this period of expansive growth and enthusiasm for higher education might turn out to be an anomaly in the region's history, and trends in the $21^{\text {st }}$ century suggest that these misgivings may have been well-founded. Figure 9 displays real state appropriations per FTE enrolled in postsecondary education, for three southern states that once prided themselves on their university systems. The drop off in South Carolina is particularly notable, especially in the Republican era beginning in 1994. In Georgia, a surge in financial support under Democratic Governors Zell Miller and Roy Barnes was reversed with the election of "Sonny" Perdue and a Republican legislature in 2002. The decline in North Carolina has been more gradual but nearly as substantial.

\section{Figure 9}

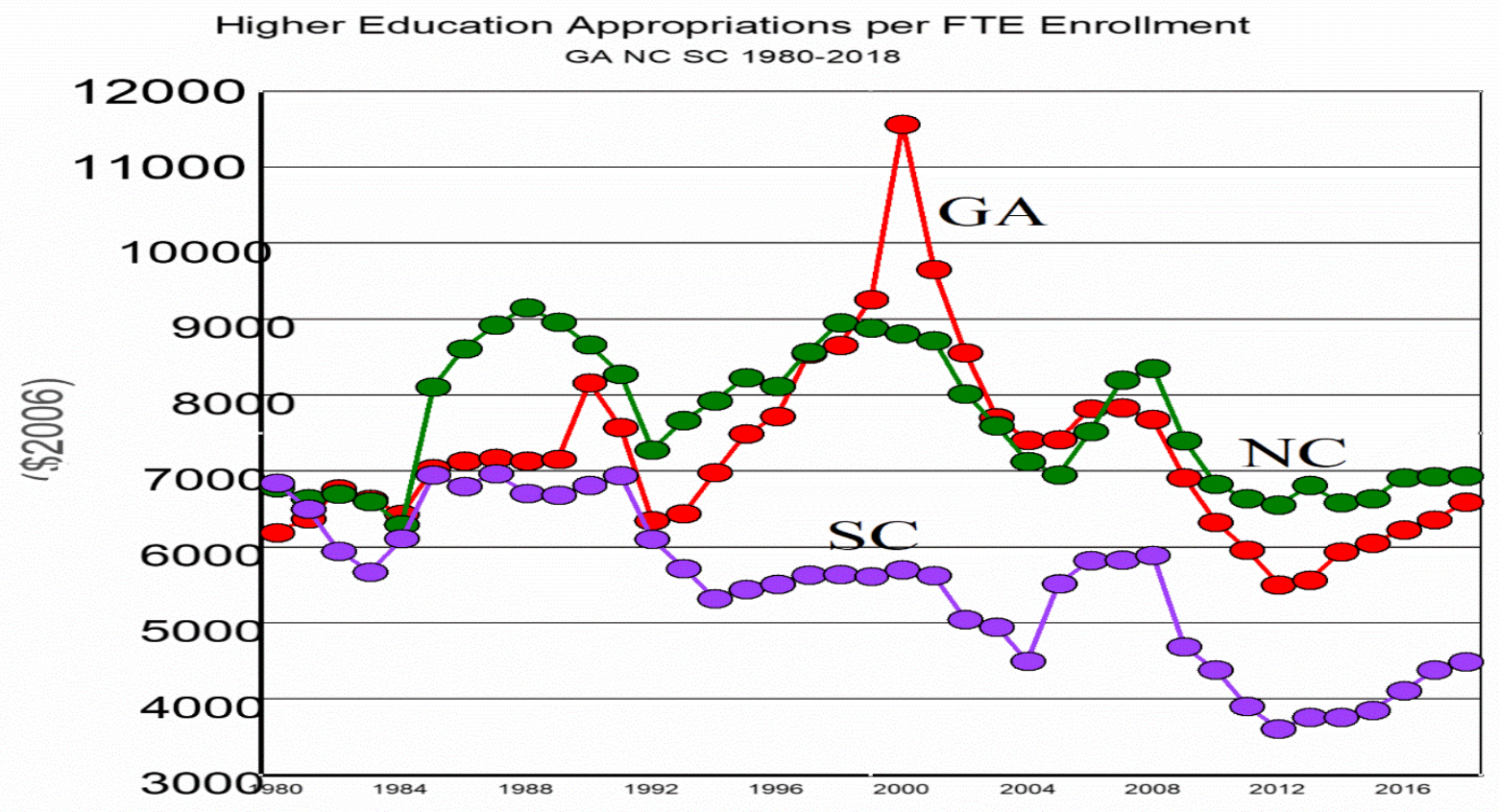

Source: State Higher Education Executive Officer Association, State Higher Education Finance reports, various years.

\footnotetext{
${ }^{99}$ Dyer, “A New Face on Southern Higher Education,” p. 293.
} 
To be sure, tight state budgets and cuts to higher education have by no means been limited to southern states. But the rise in quality of southern schools and universities was an important feature of regional economic development in the postwar era - both a reflection of and a contributor to growth -- persisting through the Civil Rights decades and even exemplified by the apparently successful response to the stresses of desegregation. A Wall Street Journal article on the relative decline of the Southern economy in recent decades states: "Many economists say the most effective way for the South to regain its momentum would be to invest more in education, which would over time create a more skilled workforce to attract employers. But Mississippi State University economist Alan Barefield notes that it is difficult to reconcile with southern states' historical desire to keep spending and taxes low." 100 Both fail to note that the region had somehow overcome this contradiction for nearly half a century. With the fin-desiecle political transition, the era of regional convergence to higher national economic standards and social norms seems to have ended.

\section{Consequences: Policies Toward Low-Income People}

After surveying dozens of studies and datasets, political scientist Matt Grossmann argues that the Republican ascendancy in state government has had only modest effects on policy trajectories. States that became red were usually conservative already, and policy overreach typically generates countervailing responses from interest groups and the courts. Grossmann concludes: "Republicans have few, if any, widespread real-world policy results to show for their state gains."101 To this, the only appropriate response is Stephen Potter's famous quip: "Yes, but not in the South." Indeed, Grossmann acknowledges that welfare cuts represent an exception to his thesis, and that the South is an outlier. He writes: "The best case for Republican impact may be distributional," citing Katherine Newman and Rourke O'Brien's evidence that southern states have shifted their tax burdens away from income and property taxes, and toward sales taxes that fall disproportionately on poorer residents. ${ }^{102}$ It is undeniable that the South has long been conservative, but Newman and O'Brien show that regional differences in tax regressivity widened sharply after 1990, coincident with the rise of Republican political control.

\footnotetext{
${ }^{100}$ Sharon Nunn, “The South's Economy is Falling Behind,” Wall Street Journal June 10, 2019.

${ }^{101}$ Grossmann, Red State Blues, p. 119.

${ }^{102}$ Red State Blues, pp. 125, 132-4; Newman and O'Brien, Taxing the Poor.
} 
One of the earliest and clearest effects of the Voting Rights Act was an increase in welfare coverage and payments. The change was most marked in plantation Black Belt counties, where elites had long managed relief programs in their own narrow interests. This effect came primarily through the election of Black county officials. ${ }^{103}$ Over a somewhat longer period, studies find broader influence at the state level. Haynie reports that greater Black representation in state legislatures tended to raise spending on health, education, and social welfare. ${ }^{104}$

Although local political control was always important, in those years welfare policy as such was largely constrained by federal rules. A feature of the conservative drift in national politics was the call to return more discretion on policy and spending allocation to the states. During the George H.W. Bush administration (1989-1992), states were encouraged to apply for waivers under the Aid to Families with Dependent Children (AFDC) program, to experiment with such features as time limits, family caps, and workfare. The real turning point, however, was passage of the Personal Responsibility and Work Opportunity Reconciliation Act in 1996 during the Clinton administration. The PRWORA ended the entitlement status of AFDC, replacing it with a time-limited assistance and work requirement program called Temporary Assistance to Needy Families (TANF). The major policy change was to assign block allocation grants to the states, who gained far more discretion on detailed conditions of welfare access. ${ }^{105}$

Responses to this new-found freedom varied widely among the states. Because benefit levels were not greatly affected by the change, the main variation was in the stringency of access rules, and by extension the pace of decline in welfare enrolment. Analysts consistently report that the single most powerful variable associated with adoption of "get tough" policies was the share of African Americans on state welfare rolls. ${ }^{106}$ Although social scientists seem averse to any mention of "region" in their interpretations, it is appropriate to point out that this key variable corresponds closely to the states of the former confederacy. Table 4 shows that African American families constituted a majority of the TANF population in all of these states except

\footnotetext{
${ }^{103}$ Bensel and Sanders, "The Impact of the Voting Rights Act on Southern Welfare Systems," pp. 56-63; Cobb, "'Somebody Done Nailed Us On the Cross.",

${ }^{104}$ Haynie, African-American Legislators, chapter 4.

${ }^{105}$ New, "State Sanctions and the Decline in Welfare Caseloads," pp. 515-517.

${ }^{106}$ Soss, et al, "Setting the Terms of Relief." Other variables with statistically significant impacts also seem closely related to region, such as political ideology and two-party competitiveness. Fellowes and Rowe, "The Politics of the New American Welfare States," confirm the prominence of race but add other influences, such as the policy choices of neighboring states. New, "State Sanctions," shows the effectiveness of restrictive policies in reducing caseloads.
} 
Florida and Texas, where the share was smaller because of the large Hispanic population. In the other nine southern states, two-thirds of TANF families were Black in 1996, compared to an average of less than one-third in the rest of the country. The table also displays the reduction in the TANF population relative to the poverty population in these states, showing that the cuts were far more drastic in the South than elsewhere

A more recent state policy juncture was the decision to support or oppose Medicaid expansion under the 2010 Patient Protection and Affordable Care Act. These choices were not intended as part of the legislation, but in upholding the Act itself in June 2012, the Supreme Court ruled that states could not be compelled to implement expansion of Medicaid coverage for the low-income population not previously covered. The financial incentives to do so remained in place, however, in that the federal government would assume initially all and eventually 90 percent of the additional cost. This subsidy was sufficient to induce most governors to support expansion: all of the Democrats and about half of the Republicans, including many conservatives from otherwise red states. As Gov. Rick Scott of Florida, a long-time opponent of Obamacare, put it: "I cannot in good conscience deny Floridians access to healthcare." Expansion in Florida was blocked, however, by the Republican-controlled legislature. ${ }^{107}$

Figure 10 shows the geography of state decisions on Medicaid expansion as of January 10, 2020. The prevalence of southern states among the non-adopters is visually evident. But the exceptions and partial exceptions are as interesting as the core pattern. Kansas, Nebraska, South Dakota and Wyoming are in various stages of deliberation and negotiation towards probable

\footnotetext{
${ }^{107}$ Barrilleaux and Rainey, “The Politics of Need,” pp. 437-441. The authors' statistical analysis concludes that governors' decisions on Medicaid expansion have been driven almost entirely by political factors - partisanship, public opinion, and ideology - and that the level of need among the citizenry plays almost no role.
} 


\section{Figure 10}

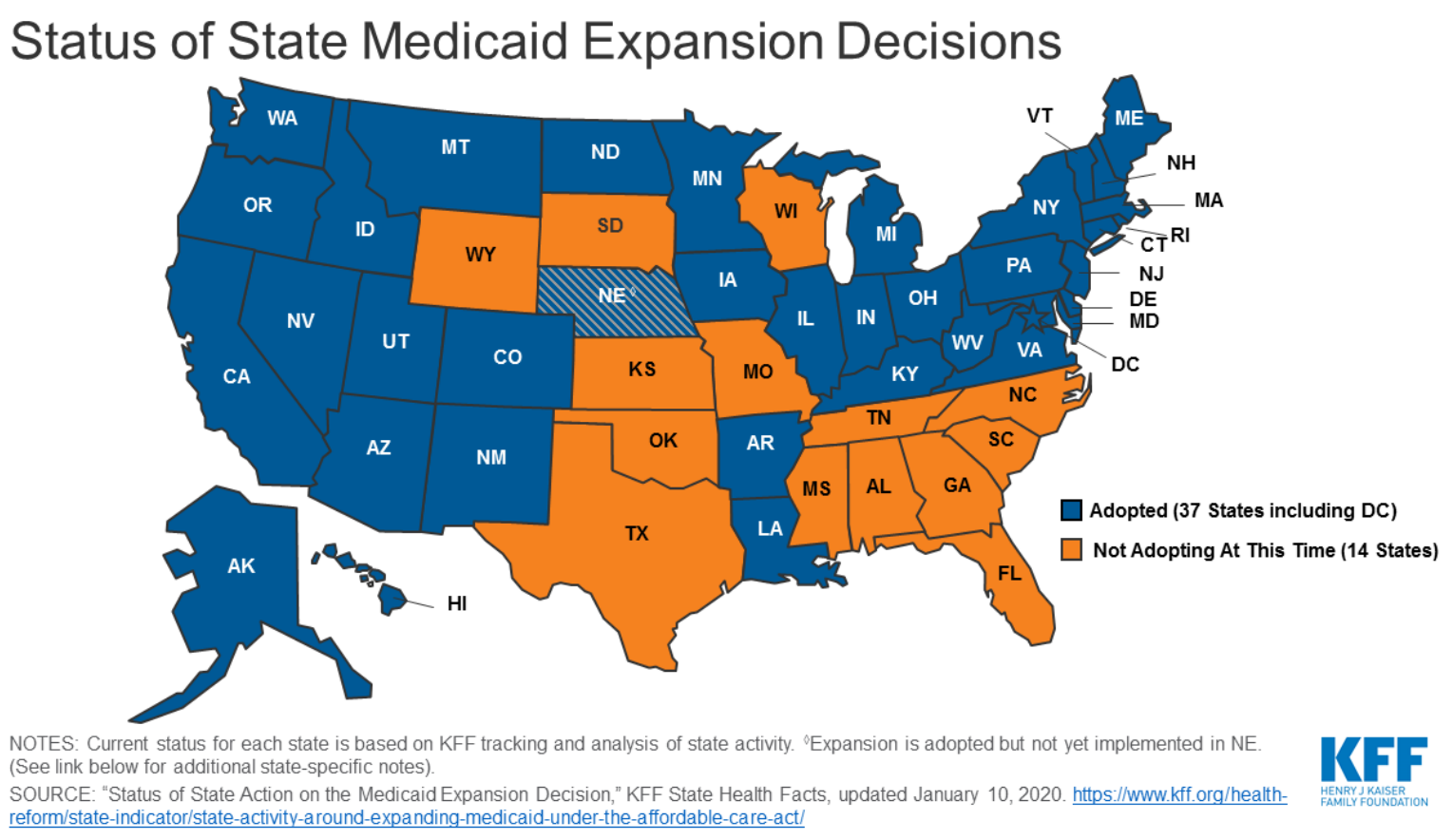

expansion (in some cases with restrictive provisions). Wisconsin has rejected Medicaid funds, but covers adults below the poverty line in Medicaid. In Missouri, the issue will be on the ballot in 2020. In other words, virtually all of the uncompromisingly rejectionist states are southern.

The exceptions within the South are equally interesting. In Virginia, Democratic governors recommended expansion after taking office in 2015 but were unable to gain legislative approval until 2018. Kentucky implemented Medicare expansion under Democratic political leadership, but Republican governor Matt Bevin actively campaigned against Obamacare in 2015 and once in office imposed a restrictive waiver. The waiver was rescinded by newly elected Democratic Governor Andy Beshear in December 2019. Arkansas approved its own version of Medicaid expansion in 2013 under Democratic Governor Mike Beebe. Republican Governor Asa Hutchinson stated in 2016: "I hope that Washington replaces Obamacare, but, until then, we would only be punishing Arkansans by turning down federal money."

A remarkable deviation from the pattern is Louisiana, perhaps the exception that proves the rule. The state rejected Medicaid expansion under Republican governors, but conservative Democrat John Bel Edwards campaigned actively on this issue in 2015, pledging to begin implementation on his first day in office. Edwards also portrayed himself as a champion of 
public schools, frequently mentioning that his wife is herself a public-school teacher. Most notably, Edwards courted the Black vote aggressively, speaking at five churches on the Sunday before the election and appearing with Black and Latino political leaders in New Orleans on Election Day. The result was an above-average turnout and a comfortable 56-44 victory in the runoff election. The new governor was true to his word, issuing an executive order on January 12 to begin the process of Medicaid expansion. Edwards was re-elected in 2019. ${ }^{108}$

The larger point is that the responses of most southern states, willingly leaving federal money on the table for political reasons, are very different from those of the 1960s and 1970s, when these states reluctantly acquiesced in such policies as desegregation of schools and hospitals because of what seemed to be the irresistible power of federal funding. The racially charged character of the topic is difficult to miss: States like Arkansas, Kentucky and West Virginia have large white poverty populations but relatively small Black shares, so Medicaid expansion is less easily color-coded than elsewhere. Virginia is now a blue state, because Black voters are part of a larger coalition dominated by metropolitan Washington DC. The example of Louisiana shows that under the right combination of circumstances, it is still possible to reassemble multiracial coalitions on economic issues, even in states where Blacks comprise a large minority share of the population. Once in place, such popular benefit programs are difficult to reverse. That resistance may in turn help to sustain the multiracial coalitions.

\section{Conclusion}

The promise of voting for Black southerners was long-delayed. But since passage of the Voting Rights Act of 1965, voting has been a powerful force for racial progress: beyond improved respect in political discourse, objective gains include greater access to public services and public-sector employment, and a fairer share of state expenditures on education and other public goods. The increase in the number of Black public officials occurred primarily in districts and municipalities where Black voters constituted a majority or near majority. In contrast, gains at the state level came through biracial coalitions, enacting pro-growth programs that benefited white as well as Black constituents.

\footnotetext{
${ }^{108}$ Nichols, "How a Democrat Can Win in the South."
} 
The consolidation of conservative Republican majorities in the southern states brought an end to this biracial political regime and a dramatic change in policies. On cultural issues, such as abortion, homosexuality, and guns, as well as economic issues like taxes and public spending, the emergent ideology of the $21^{\text {st }}$ century undoubtedly descends from traditions shaped by the region's history of slavery and segregation.

In trying to understand this development, however, changes in the behavior of white southerners deserve as much emphasis as historical continuities. Between the Voting Rights Act and the mid-1990s, the median white southerner voted for liberal-to-moderate Democrats, no doubt conservative by outside standards but well within the spectrum for the national party. Class-based partisan voting emerged during this period, which observers saw as a sign of a diminished role for race and for regional distinctiveness. If anything, the southern incomepartisan relationship during this era was steeper than elsewhere, suggesting that the persistence of conservative regional culture was largely an upper-income phenomenon. ${ }^{109}$

This apparently stable pattern then changed, beginning with an abrupt rightward shift in 1994 and more-or-less steadily thereafter, punctuated by decisive Republican gains in the midterm elections of 2010 and 2014. The swing had many causes, but this essay argues that an important contributing factor was the change in economic conditions, attributed by voters with some justification to removal of longstanding barriers to import competition in industries that were fundamental to regional prosperity. Many votes against Democratic legislators in 1994 constituted direct retaliation against President Clinton for his trade policies. The longer-term trend more likely reflected the loss of manufacturing jobs, associated with stagnant or falling real incomes, increased joblessness, and the decline of formerly robust industrial communities.

One way to frame the issue is to argue that racial tolerance and economic generosity are easier in a context of rapid economic growth. The suggestion here, however, is that the promotion of local and regional industries formed a basis for inter-racial cooperation, based not on generosity but on enlightened mutual self-interest. Removing that structure opened the door to emotional appeals rooted in regional culture or racial and ethnic scapegoating. Can new multi-racial coalitions reclaim statewide majority status? The transition in Virginia, and scattered

\footnotetext{
${ }^{109}$ Gelman et al, Red State, Poor State, argue that regional cultural differences boil down to differences between the upper-income classes in rich and poor states.
} 
election results elsewhere, suggest that this eventuality is possible. The greatest unknown is the Hispanic vote, whose impact has thus far been limited outside of Florida and Texas, despite rapid population growth. Whether the white working class rejoins this coalition may be questionable. But an equitable pro-growth political program might be good for them as well. 
Table 1. Share of Black Elected Officials Relative to Share of Voting-Age Population, 2001

\begin{tabular}{|c|c|c|c|c|c|c|c|}
\hline & $\begin{array}{l}\text { State } \\
\text { Senate }\end{array}$ & $\begin{array}{l}\text { State } \\
\text { House }\end{array}$ & $\begin{array}{l}\text { County } \\
\text { Commission }\end{array}$ & Mayor & $\begin{array}{l}\text { City } \\
\text { Council }\end{array}$ & $\begin{array}{l}\text { School } \\
\text { Board }\end{array}$ & $\begin{array}{l}\text { All } \\
\text { Elected } \\
\text { Offices }\end{array}$ \\
\hline Alabama & 0.927 & 1.04 & 0.979 & 0.427 & 0.979 & 0.427 & 0.717 \\
\hline Arkansas & 0.562 & 0.85 & 0.0 & 0.434 & 0.0 & 0.434 & 0.432 \\
\hline Florida & 1.316 & 1.068 & 0.503 & 0.269 & 0.503 & 0.269 & 0.339 \\
\hline Georgia & 0.713 & 0.789 & 0.512 & 0.196 & 0.512 & 0.196 & 0.350 \\
\hline Louisiana & 0.762 & 0.723 & 0.661 & 0.362 & 0.661 & 0.362 & 0.468 \\
\hline Mississippi & 0.62 & 0.863 & 0.749 & 0.539 & 0.749 & 0.539 & 0.565 \\
\hline North Carolina & 0.673 & 0.76 & 0.913 & 0.288 & 0.913 & 0.288 & 0.42 \\
\hline South Carolina & 0.621 & 0.721 & 0.836 & 0.377 & 0.836 & 0.377 & 0.496 \\
\hline Tennessee & 0.607 & 1.013 & 0.155 & 0.06 & 0.155 & 0.06 & 0.176 \\
\hline Texas & 0.546 & 0.782 & 0.112 & 0.248 & 0.112 & 0.248 & 0.155 \\
\hline Virginia & 0.672 & 0.591 & 0.505 & 0.117 & 0.505 & 0.117 & 0.429 \\
\hline SOUTH & & & & & & & 0.375 \\
\hline NON-SOUTH & & & & & & & 0.095 \\
\hline Illinois & & & & & & & 0.098 \\
\hline Michigan & & & & & & & 0.150 \\
\hline New Jersey & & & & & & & 0.213 \\
\hline New York & & & & & & & 0.079 \\
\hline Ohio & & & & & & & 0.143 \\
\hline Pennsylvania & & & & & & & 0.071 \\
\hline
\end{tabular}

SOURCES: Bullock and Gaddie, Triumph of Voting Rights, Table 12.4; Joint Center for Political and Economic Studies, Black Elected Officials 2001, Table 3. 
Table 2. Indices of Party Competition in Southern States, 1956-2010

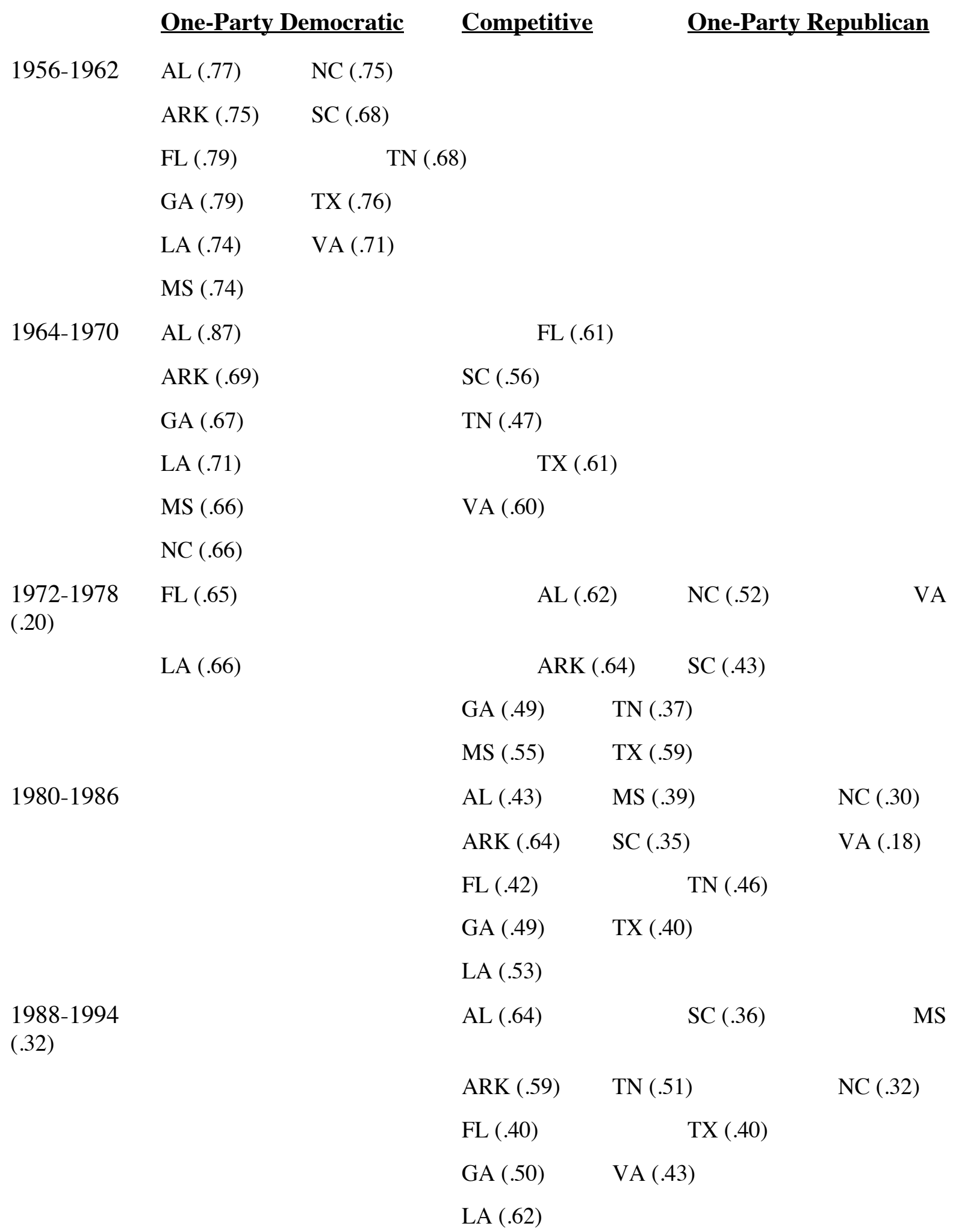


Table 2 (continued)

\section{One-Party Democratic Competitive}

2012-2017
1996-2002

ARK (.45)

FL (.40)

GA (.38)

LA (.49)

NC (.36)

SC (.36)

2004-2010

VA (.88)

FL $(.46)$
GA $(.38)$
LA $(.41)$
NC $(.43)$
VA $(.46)$
LA $(.40)$
ARK $(.35)$

ARK (.50)

AL (.30)

MS (.32)

SC (.30)

$\mathrm{TN}(.34)$

TX (.32)

$\mathrm{NC}(.34)$

TX (.33)

FL (.33)

$\mathrm{SC}(.32)$

MS (.32)

GA (.31)

$\mathrm{AL}(.28)$

TN (.23)

SOURCE: Woodard, New Southern Politics, p. 259; Gray et al, Politics in the American States, Table 3-2. The table combines "one-party Democrat" (.85-1.00) with "modified one-party Democrat" (.65-.8499); and "one-party Republican" (.00-.1499) with "modified one-party Republican" (.15-.3499). "Competitive" is .35-.6499). The figures for 2012-17 are from Gray et al and are not strictly comparable to those from Woodard. 
Table 3. Status of Black State Legislators, Southern States, 1994-2011

\begin{tabular}{|c|c|c|c|c|c|l|c|c|}
\hline \multirow{2}{*}{ Status } & \multicolumn{2}{|c|}{$\begin{array}{c}\text { Pre-1994 } \\
\text { Midterms }\end{array}$} & \multicolumn{2}{c|}{$\begin{array}{c}\text { Post-1994 } \\
\text { Midterms }\end{array}$} & \multicolumn{2}{c|}{$\begin{array}{c}\text { Pre-2010 } \\
\text { Midterms }\end{array}$} & \multicolumn{2}{c|}{$\begin{array}{c}\text { Post-2010 } \\
\text { Midterms }\end{array}$} \\
\hline & State & $\begin{array}{l}\text { State } \\
\text { Souse }\end{array}$ & $\begin{array}{l}\text { State } \\
\text { Senate }\end{array}$ & $\begin{array}{l}\text { State } \\
\text { Senate }\end{array}$ & $\begin{array}{l}\text { State } \\
\text { House }\end{array}$ & $\begin{array}{l}\text { State } \\
\text { Senate }\end{array}$ & $\begin{array}{l}\text { State } \\
\text { House }\end{array}$ & $\begin{array}{l}\text { State } \\
\text { Senate }\end{array}$ \\
\hline Majority & $\begin{array}{c}158 \\
(99.3 \%)\end{array}$ & $\begin{array}{c}43 \\
(100 \%)\end{array}$ & $\begin{array}{c}174 \\
(81.7 \%)\end{array}$ & $\begin{array}{c}61 \\
(91.0 \%)\end{array}$ & $\begin{array}{c}117 \\
(47.8 \%)\end{array}$ & $\begin{array}{c}47 \\
(58.8 \%)\end{array}$ & $\begin{array}{c}11 \\
(4.5 \%)\end{array}$ & $\begin{array}{c}4 \\
(5.6 \%)\end{array}$ \\
\hline Minority & 1 & 0 & 39 & 6 & 128 & 33 & 231 & 67 \\
& $(0.7 \%)$ & $(0.0 \%)$ & $(18.3 \%)$ & $(9.0 \%)$ & $(52.2 \%)$ & $(41.2 \%)$ & $(95.5 \%)$ & $(94.4 \%)$ \\
\hline & & & & & & & & \\
\hline Total & 159 & 43 & 213 & 67 & 245 & 80 & 242 & 71 \\
\hline
\end{tabular}

SOURCE: Bositis, Resegregation in Southern Politics? Table 1. 
Table 4. TANF-TO-POVERTY RATIOS, 1995-96 and 2016-17

\begin{tabular}{|l|c|c|c|c|}
\hline & \multicolumn{2}{|l|}{$\begin{array}{l}\text { TANF Families/Poverty } \\
\text { Population }\end{array}$} & \multicolumn{2}{l|}{ TANF Families by Race 1995 (\%) } \\
\hline & $\mathbf{1 9 9 5 - 1 9 9 6}$ & $\mathbf{2 0 1 6 - 2 0 1 7}$ & Black & Hispanic \\
\hline Alabama & 32 & 9 & 72.9 & 0.1 \\
\hline Arkansas & 33 & 5 & 58.1 & 0.5 \\
\hline Florida & 55 & 13 & 47.2 & 17.7 \\
\hline Georgia & 82 & 6 & 72.3 & 1.1 \\
\hline Louisiana & 48 & 4 & 81.6 & 0.8 \\
\hline Mississippi & 39 & 6 & 86.2 & 0.2 \\
\hline North Carolina & 74 & 7 & 63.4 & 1.8 \\
\hline South Carolina & 40 & 10 & 72.5 & 0.7 \\
\hline Tennessee & 67 & 23 & 55.2 & 0.6 \\
\hline Texas & 47 & 4 & 32.1 & 46.6 \\
\hline Virginia & 56 & 19 & 65.0 & 2.0 \\
\hline & & & & 15 \\
\hline SOUTH & 53 & 9 & 56 & 23 \\
\hline NON-SOUTH & 76 & 31 & 31 & 20.8 \\
\hline USA & 68 & 23 & 36.9 & \\
\hline
\end{tabular}

SOURCES: Center on Budget and Policy Priorities, Trends in State Caseloads and TANF-toPoverty Ratios (updated November 28, 2018); U.S. Department of Health and Family Services, Department of Family Assistance. Characteristics and Financial Circumstances of TANF Recipients, FY1996. Race for families is identified as "race of natural or adoptive parent." 


\section{References}

Abramowitz, Alan I., Brad Alexander, and Matthew Gunning. "Incumbency, Redistricting, and the Decline of Competition in U.S. House Elections," Journal of Politics 68 (2006): 75-88.

Aistrup, Joseph A. The Southern Strategy Revisited. Lexington KY: University Press of Kentucky, 1996.

Aneja, Abhay P., and Carlos F. Avenancio-Leon, "The Effect of Political Power on Labor Market Inequality: Evidence from the 1965 Voting Rights Act,” working paper (2019).

Ansolabehere, Stephen; Nathan Persily; and Charles Stewart III. "Race, Region, and Vote Choice in the 2008 Election: Implications for the Future of the Voting Rights Act," Harvard Law Review 123 (2010): 1385-1436.

Ansolabehere, Stephen; Nathan Persily; and Charles Stewart III. "Regional Differences in Racial Polarization in the 2012 Presidential Election: Implications for the Constitutionality of Section 5 of the Voting Rights Act," Harvard Law Review Forum 126 (2013): 205-220.

Autor, David H.; David Dorn; and Gordon H. Hanson. "The Geography of Trade and technology Shocks in the United States," American Economic Review 103 (2013): 220-225.

Autor, David H.; David Dorn; and Gordon H. Hanson. "The China Shock: "Learning from Labor Market Adjustment to Large Changes in Trade,” NBER Working Paper 21906 (January 2016).

Autor, David H.; David Dorn; and Gordon H. Hanson. “The China Syndrome: Local Labor Market Effects of Import Competition in the United States," American Economic Review 103 (2013): 2121-2168.

Barrilleaux, Charles, and Carlisle Rainey. "The Politics of Need: Examining Decisions to Oppose the 'Obamacare' Medicaid Expansion," State Politics and Policy Quarterly 14 (2014): 437-460.

Bass, Jack, and Walter DeVries. The Transformation of Southern Politics: Social Change and Political Consequence Since 1945. New York: Basic Books, 1976. 
Bensel, Richard F., and M. Elizabeth Sanders. "The Impact of the Voting Rights Act on Southern Welfare Systems," in Benjamin Ginsberg and Alan Stone (eds.), Do Elections Matter? Armonk, NY: M.E. Sharpe, 1986.

Berman, Ari. Give Us the Ballot: The Modern Struggle for Voting Rights in America. New York: Farrar, Straus, and Giroux, 2015.

Bernini, Andrea, Giovanni Facchini, and Cecelia Testa. "Race, Representation and Policy: Black Elected Officials and Public Spending in the US South," NICEP Working Paper: 2017-01. The University of Nottingham, 2017.

Black, Earl. Southern Governors and Civil Rights. Cambridge MA: Harvard University Press, 1976.

Black, Earl, and Merle Black. The Rise of Southern Republicans. Cambridge: Belknap Press of Harvard University Press, 2002.

Blonigen, Bruce A. "Revisiting the Evidence on Trade Policy Preferences," Journal of International Economics 85 (2011): 129-135.

Bolton, Charles C. The Hardest Deal of All: The Battle over School Desegregation in Mississippi, 1870-1980. Jackson: University Press of Mississippi, 2005.

Bonica, Adam, and Gary W. Cox. "Ideological Extremists in the U.S. Congress: Out of Step but still in office," Stanford University (2015).

Bositis, David A. Resegregation in Southern Politics? Joint Center for Political and Economic Studies Research Brief (November 2011).

Braden, Waldo W. “The Speaking of the Governors of the Deep South, 1970-1980," in Calvin M Logue and Howard Dorgan (eds.), A New Diversity in Contemporary Southern Rhetoric. Baton Rouge: Louisiana State University Press, 1987): 188-205.

Browder, Glen. The South's New Racial Politics: Inside the Race Game of Southern History. Montgomery: NewSouth Books, 2009.

Bullock, Charles S. III, and Ronald Keith Gaddie. The Triumph of Voting Rights in the South. Norman OK: University of Oklahoma Press, 2009. 
Bullock, Charles S. III, and Mark J. Rozell (eds.). The New Politics of the Old South. Fifth Edition. Lanham MD: Rowman \& Littlefield, 2014.

Burnham, Walter Dean. Voting in American Elections: The Shaping of the American Political Universe Since 1788. Edited by Thomas Ferguson and Louis Ferleger. Palo Alto: Academica Press, 2010.

Burnham, Walter Dean and Thomas Ferguson, "Americans Are Sick to Death of Both Parties: Why Our Politics Is in Worse Shape Than We Thought.” AlterNet, December 17, 2014; https://www.alternet.org/2014/12/americans-are-sick-death-both-parties-why-our-politics-worseshape-we-thought/

Button, James W. Blacks and Social Change: The Impact of the Civil Rights Movement in Southern Communities. Princeton: Princeton University Press, 1989.

Button, James W.; Barbara J. Rienzo; and Sheila L. Croucher. Blacks and the Quest for Economic Equality: The Political Economy of Employment in Southern Communities in the United States. University Park: Pennsylvania State University Press, 2009.

Byng, Michelle D. "Responding to Black Political Interests in the Post-Civil Rights Era," Sociological Inquiry 68 (1998): 203-227.

Carter, Dan T. From George Wallace to Newt Gingrich: The Role of Race in the Counterrevolution, 1963-1994. Baton Rouge: Louisiana State University Press, 1996.

Cascio, Elizabeth U. "Maternal Labor Supply and the Introduction of Kindergarten into American Public Schools,’ Journal of Human Resources 41 (2009): 140-170.

Cascio, Elizabeth U., and Ebonya Washington. "Valuing the Vote: The Redistribution of Voting Rights and State Funds following the Voting Rights Act of 1965," Quarterly Journal of Economics (2014): 379-433.

Clark, John A., and Charles L. Prysby. Southern Political Party Activists. Lexington KY: University Press of Kentucky, 2004.

Cobb, James C. “'Somebody Done Nailed Us on the Cross:' Federal Farm and Welfare Policy and the Civil Rights Movement in the Delta," Journal of American History 77 (1990): 912-936. 
Cohodas, Nadine. Strom Thurmond and the Politics of Southern Change. New York: Simon and Schuster, 1993.

Connerly, Charles E. “The Most Segregated City in America”: City Planning and Civil Rights in Birmingham, 1920-1980. Charlottesville: University of Virginia Press, 2005.

Davidson, Chandler, and Bernard Grofman (eds.). Quiet Revolution in the South: The Impact of the Voting Rights Act, 1965-1990. Princeton NJ: Princeton University Press, 1994.

Dyer, Thomas G. “A New Face on Southern Higher Education,” in Craig S. Pscoe, Karan Trahan Leathem, and Andy Ambrose (eds.), The American South in the Twentieth Century. Athens GA: University of Georgia Press, 2005.

Eisinger, Peter K. "Black Employment in Municipal Jobs: The Impact of Black Political Power," American Political Science Review 76 (1982): 380-392.

Feldman, Glenn (ed.). Painting Dixie Red. Gainesville: University Press of Florida, 2011.

Fellowes, Matthew C., and Gretchen Rowe. "Politics and the New American Welfare States," American Journal of Political Science 48 (2004): 362-373.

Fleisher, Richard. "Explaining the Change in Roll-Call Behavior of Southern Democrats," The Journal of Politics 55 (1993): 327-341.

Foner, Eric. Freedom's Lawmakers: A Directory of Black Officeholders during Reconstruction. New York: Oxford University Press, 1993.

Gaddie, Ronald Keith, and Donna R. Hoffman. "Critical Events in Contemporary Southern Politics,” in John C.Kuzenski, Laurence W. Moreland, and Robert P. Steed (eds.), Eye of the Storm: The South and Congress in an Era of Change. Westport CT: Praeger, 2001.

Gainous, Jason R.; James Button; and Barbara Rienzo. “African Americans and Municipal Employment: A Test of Two Perspectives,” Social Science Journal 44 (2007): 535-545.

Garrow, David J. Protest at Selma: Martin Luther King, Jr., and the Voting Rights Act of 1965. New Haven: Yale University Press, 1978.

Gelman, Andrew. Red State, Blue State, Rich State Poor State. Princeton University Press, 2008. 
Gerber, Jim. "Public School Expenditures in the Plantation States," Explorations in Economic History 28 (1991): 309-322.

Gray, Virginia H.; Russell L. Hanson; and Thad Kousser. Politics in the American States: A Comparative Analysis. 11 ${ }^{\text {th }}$ edition. Singapore: SAGE Publications Asia-Pacific, 2018.

Greene, Melissa Fay. Praying for Sheetrock. New York: Fawcett Columbine, 1991.

Grose, Christian R. Congress in Black and White: Race and Representation in Washington and at Home. New York: Cambridge University Press, 2011.

Grossmann, Matt. Red State Blue: How the Conservative Revolution Stalled in the States. New York: Cambridge University Press, 2019.

Hahn, Steven. A Nation Under Our Feet: Black Political Struggles in the Rural South from Slavery to the great Migration. Cambridge MA: Harvard University Press, 2003.

Hakobyan, Sushanik, and John McLaren. "Looking for Local Labor-Market Effects of NAFTA,” Review of Economics and Statistics 98 (2016): 728-41.

Hallicoussis, Dennis; Kenneth Ng; and Nancy Virts. "Property Ownership and Educational Discrimination in the South," Journal of Education Finance 35 (2009): 128-139.

Hanks, Lawrence J. The Struggle for Black Political Empowerment in Three Georgia Counties. Knoxville: University of Tennessee Press, 1987.

Harvey, Gordon E. A Question of Justice: New South Governors and Education 1968-1976. Tuscaloosa: University of Alabama Press, 2002.

Harvard, William C. (ed.). The Changing Politics of the South. Baton Rouge: Louisiana State University Press, 1972.

Haynie, Kerry L. African-American Legislators in the American States. New York: Columbia University Press, 2001.

Hirsch, Barry T.; David A. McPherson; Wayne Vroman. "Estimates of Union Density by State," Monthly Labor Review 124 (2001). Updated annually at unionstats.com. 
Hood, M. V. III, Quentin Kidd, and Irwin L. Morris. The Rational Southerner: Black

Mobilization, Republican Growth, and the Partisan Transformation of the American South. New York: Oxford University Press, 2012.

Hopkins, Daniel J. The Increasingly United States: How and Why American Political Behavior Nationalized. Chicago: University of Chicago Press, 2018.

Jacobsen, Gary C. "The 1994 House Elections in Perspective," Political Science Quarterly 111 (1996): 203-223.

Jenkins, Robert L., and William A. Person. "Educational Reform in Mississippi," in David J. Vold and Joseph L. DeVitis, School Reform in the Deep South. Tuscaloosa: University Press of Alabama, 1991.

Jones, Daniel P., Werner Troesken, and Randall Walsh. “A Poll Tax by any Other Name: The Political Economy of Disenfranchisement," NBER Working Paper 18612 (2012).

Key, V.O. Southern Politics in State and Nation. New York: Knopf, 1949.

King-Meadows, Tyson D. When the Letter Betrays the Spirit. Lanham MD: Lexington Books, 2011.

Kousser, J. Morgan. The Shaping of Southern Politics: Suffrage Restrictions and the Establishment of the One-Party South. New Haven CT: Yale University Press, 1974.

Kousser, J. Morgan. "Progressivism for Middle-Class Whites Only: North Carolina Education, 1880-1910," Journal of Southern History 46 (1980): 169-194.

Kousser, J. Morgan. “Do the Facts of Voting Rights Support Chief Justice Roberts' Opinion in Shelby County?" Transatlantica (2015).

Kuklinski, James H., Michael D. Cobb, and Martin Gilens. "Racial Attitudes and the 'New South.'” Journal of Politics 59 (1997): 323-349.

Kuziemko, Ilyana, and Ebonya Washington. "Why Did the Democrats Lose the South? Bringing New Data to an Old Debate," American Economic Review 108 (2018): 2830-67.

Lamis, Alexander P. The Two-Party South. New York: Oxford University Press, 1984. 
Lamis, Alexander P. The Two-Party South: Expanded Edition. New York: Oxford University Press, 1988.

Lamis, Alexander P. Southern Politics in the 1990s. Baton Rouge: Louisiana State University Press, 1999.

Lawson, Steven F. Black Ballots: Voting Rights in the South, 1944-1969. New York: Columbia University Press, 1976.

Lawson, Steven F. In Pursuit of Power: Southern Blacks and Electoral Politics, 1965-1982. New York: Columbia University Press, 1985.

Lefkowitz, Bonnie. Community Health Centers: A Movement and the People Who Made It Happen. New Brunswick NJ: Rutgers University Press, 2007.

Logan, Trevon D. “Do Black Politicians Matter?” NBER Working Paper (2018).

Margo, Robert A. Disfranchisement, School Finance, and the Economics of Segregated Schools in the U.S. South, 1890-1910. New York: Garland Press, 1985.

Maxwell, Angie, and Todd G. Shields (eds.). Unlocking V. O. Key, Jr.. Fayetteville: University of Arkansas Press, 2011.

Maxwell, Angie, and Todd Shields. The Long Southern Strategy: How Chasing White Voters in the South Changed American Politics. New York: Oxford University Press, 2019.

May, Gary. Bending Towards Justice: The Voting Rights Act and the Transformation of American Democracy. New York: Basic Books, 2013.

McDonald, Laughlin. Voting Rights Odyssey: Black Enfranchisement in Georgia. Cambridge: Cambridge University Press, 2003.

McKee, Seth C. Republican Ascendancy in Southern U.S. House Elections. Philadelphia: Westview Press, 2010.

Menifield, Charles E., and Stephen D. Shaffer (eds.). Politics in the New South. Albany: State University of New York Press, 2005. 
Minchin, Timothy. Empty Mills: The Fight Against Imports and the Decline of the U.S. Textile Industry. Lanham MD: Littlefield Publishers, 2013.

Mittelhauser, Mark. "Employment Trends in Textiles and Apparel, 1973-2005," Monthly Labor Review (August 1997): 24-34.

Moreland, Laurence W. "Ideological and Issue Bases of Southern Parties," in Tod A. Baker, Charles D. Hadley, Robert P. Steed, and Laurence W. Moreland (eds.), Political Parties in the Southern States. Westport CT: Praeger, 1990.

Nadeau, Richard, and Harold W. Stanley. "Class Polarization and Partisanship among Native Southern Whites, 1952-90,” American Journal of Political Science 37 (1993): 900-919.

Nadeau, Richard; Richard G. Niemi; Harold Stanley; Jean-Francois Dodbout. "Class, Party and South/Non-South Differences," American Politics Research 32 (2004): 52-67.

New, Michael J. "State Sanctions and the Decline in Welfare Caseloads," Cato Journal 28 (2008): 515-533.

Newman, Katherine, and Rourke O'Brien. Taxing the Poor; Doing Damage to the Truly Disadvantaged. Berkeley: University of California Press, 2011.

Nichols, John. "How a Democrat Can Win in the South," The Nation (November 23, 2015).

Nye, John V. C.; Ilia Ranier; and Thomas Stratmann. "Do Black Mayors Improve Black Employment Outcomes?" The Journal of Law, Economics, and Organization (2014): 1-48.

Perry, Huey L. “The Socioeconomic Impact of Black Political Empowerment in a Rural Southern Locality," Rural Sociology 45 (1980): 207-222.

Perry, Hugh L. “The Evolution and Impact of Biracial Coalitions in Birmingham and New Orleans," in Rufus Browning, Rogers Marshall, and David H. Tabb (eds.), Racial Politics in American Cities. $3^{\text {rd }}$ edition. New York: Longman, 2003.

Petrocik, John R., and Scott W. Desposato. “The Partisan Consequences of Majority-Minority Redistricting in the South, 1992 and 1994,” The Journal of Politics 60 (1998): 613-633. 
Preuhs, Robert R. “The Conditional Effects of Minority Descriptive Representation: Black Legislators and policy Influence in the American States," Journal of Politics 68 (2006): 585-99.

Price, Margaret. The Negro Voter in the South. Atlanta GA: Southern Regional Council, 1957.

Price, Margaret. The Negro and the Ballot in the South. Atlanta GA: Southern Regional Council, 1959.

Reber, Sarah. "From Separate and Unequal to Integrated and Equal?" Review of Economics and Statistics 93 (2011): 404-415.

Rudder, Charles F. "Education Reform in Alabama, 1972-1989,” in David J. Vold and Joseph L. DeVitis (eds.), School Reform in the Deep South. Tuscaloosa: University Press of Alabama, 1991.

Rutenberg, Jim. “Overcome,” New York Times Magazine August 2, 2015.

Sanders, Randy. Mighty Peculiar Elections: The New South Gubernatorial Elections of 1970 and the Changing Politics of Race. Gainesville: University Press of Florida, 2002.

Scheve, Kenneth F., and Matthew J. Slaughter. Globalization and the Perceptions of American Workers. Washington DC: Institute for International Economics, 2001.

Scheve, Kenneth F., and Matthew J. Slaughter. "What Determines Trade Policy Preferences?" Journal of International Economics 54 (2001): 267-292.

Shafer, Byron E., and Richard Johnston. The End of Southern Exceptionalism: Class, Race and Partisan Change in the Postwar South. Cambridge: Harvard University Press, 2006.

Shaffer, William R. "Ideological Trends Among Southern U.S. Democratic Senators," American Politics Quarterly 15 (1987): 299-324.

Smith, Stephen Samuel. Boom for Whom? Education, Desegregation and Development in Charlotte. Albany: State University of New York Press, 2004.

Soss, Joe; Sanford F. Schram; Thomas Vartanian; and Erin O'Brien. "Setting the Terms of Relief: Explaining State Policy Choices in the Devolution Revolution," American Journal of Political Science 45 (2001): 378-395. 
Southern Education Foundation. A New Majority: Low Income Student in the South's Public Schools (2007), with updates in 2013 and 2015.

Southern Education Foundation. A New Diverse Majority: Students of Color in the South's Public Schools (2010).

Stanley, Harold W. Voter Mobilization and the Politics of Race. New York: Praeger, 1987.

Stern, Mark. Calculating Visions: Kennedy, Johnson, and Civil Rights. New Brunswick NJ:

Rutgers University Press, 1992.

Texeira, Ruy, and Alan Abramowitz. "The Decline of the White Working Class and the Rise of a Mass Upper Middle Class,” Brookings Working Paper (April 2008).

Thernstrom, Abigail. Whose Votes Count: Affirmative Action and Minority Voting Rights. Cambridge: Harvard University Press, 1987.

Thernstrom, Abigail. Voting Rights - And Wrongs. Washington DC: AEI Press, 2008.

Thompson, Joel A. “The Voting Rights Act in North Carolina: An Evaluation,"Publius 16 (1986): 139-153.

Thornton, J. Mills. Dividing Lines. Tuscaloosa: University of Alabama Press, 2002.

Timpone, Richard J. "Mass mobilization or Government Intervention? The Growth of Black Registration in the South," Journal of Politics 57 (1995): 425-442.

U.S. Commission on Civil Rights, Political Participation. Washington DC: Government Printing Office, 1968.

U.S. Commission on Civil Rights, The Voting Rights Act: Ten Years After. Washington DC; Government Printing Office, 1975.

U.S. Department of Labor. Report to Congress: The Past, Present, and Future of Employment in the Textile and Apparel Industries: An Overview. May, 2004.

U.S. Equal Employment Opportunity Commission. Job Patterns for Minorities and Women in Private Industry. 1990, 2002. 
U.S. International Trade Administration. Office of Textiles and Apparel (OTEXA). Trade Data: U.S. Imports and Exports of Textiles and Apparel. http://otexa.trade.gov/msrpoint.htm.

Valentino, Nicholas A., and David O. Sears. "Old Times There are not Forgotten: Partisan Realignment in the Contemporary South," American Journal of Political Science 49 (2005): 672688 .

Vallely, Richard M. The Two Reconstructions: The Struggle for Black Enfranchisement. Chicago: University of Chicago Press, 2004.

Van Wingen, John, and David Valentine. "Partisan Politics: A One-and-a-Half, No-Party System," in James F. Lea (ed.), Contemporary Southern Politics. Baton Rouge: Louisiana State University Press, 1988.

Walters, Pamela Barnhouse; David R. James; and Holly J. McCammon. "Citizenship and Public Schools: Accounting for Racial Inequality in Education in the Pre- and Post-Disfranchisement South," American Sociological Review 62 (1997): 34-52.

Washington, Ebonya. "Do Majority-Black Districts Limit Blacks' Representation? The Case of the 1990 Redistricting," Journal of Law and Economics 55 (2012): 251-274.

Watters, Pat, and Reese Cleghorn. Climbing Jacob's Ladder: The Arrival of Negroes in Southern Politics. New York: Harcourt, Brace and World, 1967.

Wirt, Frederick M. The Politics of Southern Inequality: Law and Social Change in a Mississippi County. Chicago: Aldine, 1970.

Wirt, Frederick M. "We Ain't What We Was": Civil Rights in the New South. Durham NC: Duke University Press, 1997.

Woodard, J. David. The New Southern Politics. Second Edition. Boulder CO: Lynne Rienner Publishers, 2013.

Wright, Gavin. Sharing the Prize: The Economics of the Civil Rights Revolution in the American South. Cambridge MA: Harvard University Press, 2013.

Zengerle, Jason. "The New Racism - This is How the Civil Rights Movement Ends," The New Republic August 11, 2014. 